\title{
Battery Crush Test Procedures in Standards and Regulation: Need for Augmentation and Harmonisation
}

\author{
Bhavya Kotak $^{1}$, Yash Kotak ${ }^{1, *(\mathbb{D})}$, Katja Brade ${ }^{2}$, Tibor Kubjatko ${ }^{3}$ and Hans-Georg Schweiger ${ }^{1}(\mathbb{D}$ \\ 1 Technische Hochschule Ingolstadt, CARISSMA Institute of Electric, Connected and Secure \\ Mobility (C-ECOS), Esplanade 10, 85049 Ingolstadt, Germany; BhavyaSatishbhai.Kotak@carissma.eu (B.K.); \\ Hans-Georg.Schweiger@thi.de (H.-G.S.) \\ 2 Global Battery Competence Team, AVL Deutschland GmbH, Marie-Curie-Straße 1, 85055 Ingolstadt, \\ Germany; Katja.Brade@avl.com \\ 3 Institute for Forensic Research and Education, University Zilina, Univerzitná 8215/1, 01026 Žilina, Slovakia; \\ tkubjatko@gmail.com \\ * Correspondence: Yash.Kotak@carissma.eu; Tel.: +49-841-93483412
}

Citation: Kotak, B.; Kotak, Y.; Brade, K.; Kubjatko, T.; Schweiger, H.-G. Battery Crush Test Procedures in Standards and Regulation: Need for Augmentation and Harmonisation. Batteries 2021, 7, 63. https://doi.org/ $10.3390 /$ batteries7030063

Academic Editor: Seung-Wan Song

Received: 7 July 2021

Accepted: 13 September 2021

Published: 16 September 2021

Publisher's Note: MDPI stays neutral with regard to jurisdictional claims in published maps and institutional affiliations.

Copyright: (c) 2021 by the authors. Licensee MDPI, Basel, Switzerland. This article is an open access article distributed under the terms and conditions of the Creative Commons Attribution (CC BY) license (https:// creativecommons.org/licenses/by/ $4.0 /)$.

\begin{abstract}
Battery safety is a prominent concern for the deployment of electric vehicles (EVs). The battery powering an EV contains highly energetic active materials and flammable organic electrolytes. Usually, an EV battery catches fire due to its thermal runaway, either immediately at the time of the accident or can take a while to gain enough heat to ignite the battery chemicals. There are numerous battery abuse testing standards and regulations available globally. Therefore, battery manufacturers are always in dilemma to choose the safest one. Henceforth, to find the optimal outcome of these two major issues, six standards (SAE J2464:2009, GB/T 31485-2015:2015, FreedomCAR:2006, ISO 124053:2014, IEC 62660-2:2010, and SAND2017-6295:2017) and two regulations (UN/ECE-R100.02:2013 and GTR 20:2018), that are followed by more than fifty countries in the world, are investigated in terms of their abuse battery testing conditions (crush test). This research proves that there is a need for (a) augmenting these standards and regulations as they do not consider real-life vehicle crash scenarios, and (b) one harmonised framework should be developed, which can be adopted worldwide. These outcomes will solve the battery manufacturers dilemma and will also increase the safety of EV consumers.
\end{abstract}

Keywords: lithium-ion battery; electric vehicle battery; battery standard; battery regulation; battery testing standard; battery testing regulation; abuse testing; harmonising battery standard; crush test procedure; battery incidents; battery standard and regulation augmentation

\section{Introduction}

To realize a sustainable energy supply, researchers seek to substitute the use of traditional fossil fuels with clean and renewable energy resources. One of the potential solutions is to move from internal combustion engine (ICE) vehicles, i.e., gasoline vehicles, to vehicles that are powered by electricity, or alternative fuels like biofuels, hydrogen, liquefied natural gas (LNG), compressed natural gas (CNG), or hybrid vehicles (a combination of the aforementioned fuels) [1-3]. However, research has demonstrated that vehicles powered by electricity, i.e., electric vehicles (EVs) are the most effective solution [4-9]. These can reduce environmental pollution and will subsequently help to avoid global warming and climate change [10-13].

In recent years, globally the automotive industry has noticed a significant deployment of EVs in the market [3,14,15]. For example, in the year 2018, Europe (EU) attained more than one million EVs in the market [16]. Numerous researchers from a companies such as Shell Deutschland and Prognos AG including academicians such as Kugler et al. predicted the increment in the future sales of EVs [17,18]. This increment is not only due to technological advancement but is also policy-driven, as mentioned in the report of 
"Global EV Outlook 2020" [19]. As per the International Energy Agency (IEA), there will be 125 million EVs around the world by the year 2030 [20], and similar further information regarding the prediction and the future stock of EVs in Germany was researched by Machuca et al. and Kahn [14,21].

According to Spielbauer et. al., it is anticipated that the battery fire incidents and the severity of such incidents will increase in the future due to, (a) the rise in energy density of the new cells that are being developed, and (b) an increasing demand of EVs and the batteries that are used within EVs [22]. According to Wang et al., Kubjatko, Goodman et al. and Pan et al. EVs facing an accident can mechanically deform, malfunction, or can completely fail [23-25] the battery. Some of the primary reasons that can cause battery failure are [26]:

1. Internal cell short circuit: This kind of severe event can happen abruptly and without any pre-warning. Zhao et. al. and Larsson found that this event can occur because of multiple reasons such as mechanical deformation or manufacturing faults. They also noticed that another reason for an internal short circuit can be the dendrite formation within the cells $[27,28]$. According to Ahlberg Tidblad [29], this is a particularly disturbing cause because this type of failure occurs in batteries that are complied with industry standards;

2. Mechanical deformation and impact: This cause can easily initiate an internal short circuit which consequently leads to a fire. Acute deformation can be due to certain types of crashes or ground surface conditions. Zhu et al. noted that battery packs are susceptible to penetration due to side collisions and road debris impacts [30]. The research conducted by Trattnig and Leitgeb [31] showed that the absolute scenario in a car crash can be the amalgamation of leaking fluid or gases near ignition sources like electrical arcs and/or hot surfaces;

3. Charge: The purpose for which the batteries are tailored is to collect a specific amount of energy over a definite period of time. In the instances where limits are surpassed, due to rapid charging or overcharging, the battery performance can degrade, or it can even fail completely [26];

4. Discharge: Over discharge occurs when the battery cells are discharged below their manufacturer recommended minimum voltage. During this process, the conductive copper particles are released in the electrolyte, which consequently leads to an internal short circuit of the battery. Usually, battery safety systems are there to stop such situations. However, if such a safety system fails or the battery is abused, there is a possibility of battery failure [32];

5. External short circuit: This type of the short circuit also falls under the category of an electric abuse, which can easily destabilise the battery. An external short circuit happens when the battery faces an impact and/or deformation [26];

6. High-temperature exposure: In real-time applications, the battery needs to be cooled during its operation: however, if the ambient temperature is higher than the internal temperature, battery decomposition mechanisms are triggered causing the battery to produce extreme levels of heat. This high level of heat can result in an internal short circuit or thermal runaway, which consequently reduces the safety margin [26];

7. Thermal runaway: In a battery, when exothermic chemical reactions are producing more heat than is being dissipated, it enters the thermal runaway condition. In case of severe accidents, because of thermal runaway, the battery can emit heat/fumes, catch fire, or in a worst-case scenario explode [6,24,33-36].

There are negligible data available in relation to the incidences of EV fires; however, according to Norwegian insurance companies, a study conducted by [26] the percentage of EV fire accidents is approximate $4.8 \%$, out of the total number of vehicle fire accidents. Moreover, Gehandler et al. [37] found that on an average one vehicle fire that occurs every year during battery charging in multistorey car parking or big garages. Some of such catastrophic battery incidents around the world are presented in Table 1. 
Table 1. List of battery incidents [38-68].

\begin{tabular}{|c|c|c|c|}
\hline Year & Region/Country & Vehicle & Incident and Cause \\
\hline 2010 & Scandinavia & Nissan Qashqai & Vehicle caught fire while charging \\
\hline 2011 & China & Zotye M300 EV & $\begin{array}{l}\text { Vehicle caught fire while driving and hence all-electric taxis } \\
\text { were temporary pulled off the streets }\end{array}$ \\
\hline 2011 & USA & Chevrolet Volt & $\begin{array}{c}\text { Fire emerged due to leaking coolant three weeks after crash } \\
\text { test }\end{array}$ \\
\hline 2012 & USA & General Motor vehicles & $\begin{array}{l}\text { Battery exploded due to incompatible operating cycle and } \\
\text { battery prototype during tests }\end{array}$ \\
\hline 2012 & USA & Fisker Karma & $\begin{array}{l}\text { Rate of fire: Two per thousand. Usually, a vehicle catches } \\
\text { fires while it is parked }\end{array}$ \\
\hline 2012 & USA & $\begin{array}{l}\text { Three Toyota Prius and Sixteen } \\
\text { Fisker Karma }\end{array}$ & $\begin{array}{l}\text { During a hurricane, vehicles caught fire when immersed in } \\
\text { seawater as it worked as the conductor between both +ve } \\
\text { and - ve battery poles }\end{array}$ \\
\hline 2012 & Sweden & Fiat 500 & Fire ignited in the engine compartment while charging \\
\hline 2013 & France & Two Bolloré Bluecar & $\begin{array}{l}\text { First vehicle caught fire while parked and the fire spread to } \\
\text { the second one as well }\end{array}$ \\
\hline 2013 & Mexico & Three Tesla Model S & $\begin{array}{l}\text { Vehicle caught fire by hitting road debris, tree and the } \\
\text { concrete wall in less than two months. Consequently, Tesla } \\
\text { was pushed to reinforce the vehicle construction }\end{array}$ \\
\hline 2013 & Japan & Mitsubishi Outlander PHEV & $\begin{array}{l}\text { Battery overheating issue identified so production was } \\
\text { stopped for five months }\end{array}$ \\
\hline 2014 & Canada & Tesla Model S & $\begin{array}{l}\text { Vehicle caught fire while parked in the garage and was } \\
\text { bought only } 4 \text { months prior to the incident }\end{array}$ \\
\hline 2015 & Norway & $\mathrm{EV}$ & $\begin{array}{l}\text { Vehicle faced accident with a train and caught fire after two } \\
\text { hours, which took a long time to extinguish }\end{array}$ \\
\hline 2016 & Norway & Tesla Model S & $\begin{array}{l}\text { Caught fire due to short circuit while charging at } \\
\text { supercharger station }\end{array}$ \\
\hline 2016 & France & Tesla Model S & Faulty electric connection caused a fire during the test drive \\
\hline 2017 & UK & Smart Fortwo electric drive & Faulty electricals caused a fire while charging \\
\hline 2017 & China & Tesla Model X & $\begin{array}{l}\text { Vehicle was at high speed and caught fire after the crash. } \\
\text { Backseat passengers evacuated via front doors }\end{array}$ \\
\hline 2017 & USA & Tesla Model X & $\begin{array}{l}\text { Vehicle caught fire after the crash and was re-ignited on the } \\
\text { tow truck and third time at the tow yard }\end{array}$ \\
\hline 2018 & Thailand & Porsche Panamera & $\begin{array}{l}\text { Vehicle was plugged in and was being charged from the } \\
\text { house socket when it caught fire }\end{array}$ \\
\hline 2018 & The Netherlands & Jaguar I-Pace & Newly delivered vehicle caught fire while parked \\
\hline 2018 & USA & Tesla Model X & $\begin{array}{l}\text { Vehicle caught fire after the crash and was re-ignited within } \\
\text { a few days two times, while parked in the tow yard }\end{array}$ \\
\hline 2018 & USA & Tesla Model X & $\begin{array}{l}\text { Vehicle caught fire after the crash and was extinguished } \\
\text { on-site with the help of an extinguisher but was re-ignited } \\
\text { two times within a week at the tow yard }\end{array}$ \\
\hline 2018 & USA & Tesla Model S & $\begin{array}{l}\text { Battery casing was ruptured and the vehicle caught fire } \\
\text { immediately after hitting the pole and nearby wall. Fire } \\
\text { re-ignited two times, (a) while loading on the tow truck, and } \\
\text { (b) at the tow yard }\end{array}$ \\
\hline 2018 & USA & Tesla Model S & Battery venting caused a fire while driving \\
\hline 2018 & USA & Tesla Model S & $\begin{array}{l}\text { Fire started in the parking area and was re-ignited in the } \\
\text { tow yard }\end{array}$ \\
\hline
\end{tabular}


Table 1. Cont.

\begin{tabular}{|c|c|c|c|}
\hline Year & Region/Country & Vehicle & Incident and Cause \\
\hline 2018 & USA & Tesla Model S & $\begin{array}{l}\text { Vehicle caught fire after the crash which was extinguished } \\
\text { swiftly but was reignited at the time of loading on the truck } \\
\text { and thereafter at the tow yard }\end{array}$ \\
\hline 2018 & USA & Tesla Model S & $\begin{array}{l}\text { Parked vehicle caught fire two times in the workshop } \\
\text { parking area }\end{array}$ \\
\hline 2018 & USA & Tesla Model S & Caught fire during driving and was extinguished swiftly \\
\hline 2018 & Thailand & Porsche Panamera, PHEV & $\begin{array}{l}\text { Caught fire while charging from the home socket. } \\
\text { Consequently, the fire was spread throughout the home }\end{array}$ \\
\hline 2018 & Switzerland & Tesla, BEV & $\begin{array}{l}\text { Vehicle was turned over after crashing with a barrier and } \\
\text { immediately caught fire }\end{array}$ \\
\hline 2018 & China \& Spain & $\begin{array}{l}\text { Tesla, BEV and BMW i3 REx, } \\
\text { PHEV }\end{array}$ & $\begin{array}{l}\text { Unknown spontaneous ignition caused the fire in the } \\
\text { parked vehicle }\end{array}$ \\
\hline 2018 & China & Zhong Tai, BEV and 3 other BEVs & $\begin{array}{l}\text { Fire was ignited without any accident. Two vehicles caught } \\
\text { fire during charging and rest while driving }\end{array}$ \\
\hline 2019 & The Netherlands & BMW I8 & Caught fire in the showroom and was quenched with water \\
\hline 2019 & China & 3 BJEV minivans & $\begin{array}{l}\text { Companies do not prefer this model anymore as it catches } \\
\text { fire while charging }\end{array}$ \\
\hline 2019 & China & Tesla Model S & $\begin{array}{l}\text { Rapid development of fire was noticed due to battery } \\
\text { venting within } 30 \text { min of the arrival of a vehicle while it was } \\
\text { parked in the garage }\end{array}$ \\
\hline
\end{tabular}

Based on the analysis (causes and comments) of Table 1 and by [27,69-71], it can be said that EV batteries are prone to failure in the case of accidents, i.e., there is a risk of the battery catching fire immediately after the accident, or it can have a delayed event. Thus, it is important to develop a safer and reliable battery, i.e., correlated risks can be managed to achieve a suitable level of safety on which the consumer can rely [72-75]. To develop such a battery, several regulatory bodies around the world have developed various battery standards and regulations (as mentioned in Section 2). These standards and regulations have a variety of testing procedures known as abuse tests. These abuse testing procedures have various testing conditions and parameters within them to test the batteries. One of such abuse tests is known as the crush test, which is used in this study along with its variety of conditions and parameters from the selected standards and a regulation to justify the need for augmentation and harmonisation (refer Section 3). Further, Section 4 discusses the findings and concludes this research. Overall, based on the authors' knowledge this study is distinct because there is no single literature available that provides a review of numerous standards and regulations with a justification of augmenting and harmonising the standards and regulations along with suggestions and future work.

\section{Standards and Regulations}

Standards and regulations can be considered as the foundation for the advancement and progress of products such as EV batteries. There are numerous standards and regulations developed at European, international, and national levels. For example, at the National level, there are many countries such as the United States of America (USA), Korea and India that have their own standards such as FreedomCAR:2006, KMVSS18-3 and AIS-048 respectively. Similarly, The United Nations Economic Commission for Europe (UNECE) developed regulations such as GTR No. 20 and UNECE R100. However, some of the exemplary EV battery standards and regulations are only explained in this section [76]. 


\subsection{Standards}

A standard is a guiding document that covers the technical aspects of the product and presents a way of repeating something. These are framed with the help of product relevant parties such as manufacturers, products, processes, services, and consumers [77].

\subsubsection{European}

According to the European regulation 1025/2012, European standards are developed by European standards organizations (ESOs) such as the European Committee for Standardisation (CEN) and the European Committee for Electrotechnical Standardization (CENELEC). The standards by CEN and CENLEC are developed by the Technical Committee (TC), the team of experts accountable for building the standards in a specific sector. Each TC has a defined scope, within which the identified standards are developed. For large programs of work, a subcommittee is usually established within a TC [78,79].

European Committee for Standardisation (CEN): CEN brings together the National Standardization Bodies of thirty-four European countries and is responsible for defining and building standards, and other technical documents concerning various kinds of materials, processes, products and services at the European level. In addition, CEN also produces other documents, such as technical specifications, reports, and workshop agreements [80].

European Committee for Electrotechnical Standardization (CENELEC): It is one of the technical organizations responsible for standardization in the electrotechnical engineering field that works on a non-profit basis. It supports the development of the Single European Market by facilitating trade between countries and cutting the compliance costs $[81,82]$.

It is worthwhile to note here that CENLEC is also referred to as CLC in some documents and the designed standards. The TCs from CEN and CENLEC that are involved in the developments of EV standards are, (a) CEN/TC 301, "road vehicles"; (b) CLC/TC 69X, "Electric systems for electric road vehicles"; (c) CLC/TC 23BX, "switches, boxes and enclosures for household and similar purposes, plugs and socket-outlets for direct-current (DC) and for the charging of EVs including their connectors"; and (d) CLC/TC 64, "electrical installations and protection against electric shock" [83].

\subsubsection{International}

International Organisation for Standardisation (ISO): It is an autonomous, non-governmental international organization consisting of 165 national standards bodies including Europe. CEN made an agreement in the year 1991 for technical co-operation with the ISO, which is known as the Vienna Agreement. This was framed to prevent duplication of efforts and decrease time for developing standards. Exemplary TCs are, (a) ISO/TC 22, "road vehicles"; (b) ISO/TC 22/SC 37, "electrically propelled vehicles"; and (c) ISO/TC 22/SC 38, "motorcycles and mopeds". With the help of experts in TCs of European and international organisations, standards such as ISO 12405-3:2014 "electrically propelled road vehiclestest specification for lithium-ion traction battery packs and system" [84] are developed for vehicles (including EVs). This standard is helpful to vehicle manufacturers as it specifies the test procedure and the related safety requirements for the traction battery developed especially for the propulsion of road vehicles $[85,86]$.

International Electrotechnical Commission (IEC): IEC was founded in the year 1906 for the development and publication of international standards for electrotechnology (combination of all electrical, electronic, and related technologies). It brings together more than 170 countries and provides a global, neutral, and independent standardization platform. IEC and CENLEC work together towards European and international standards building activities in the electrical division. Both organizations agreed to the framework in the year 1996, known as the Dresden Agreement. After 20 years of a fruitful partnership both organizations signed another agreement, known as the Frankfurt Agreement in the year 2016. Some of the exemplary TCs are, (a) IEC TC 21, "secondary cells and batteries"; (b) IEC TC 21/SC 21A, "secondary cells and batteries containing alkaline or other non-acid electrolytes"; (c) IEC TC 69, "electric road vehicles and electric industrial trucks"; (d) IEC 
TC 21/PT 62984, "secondary high-temperature cells and batteries"; and (e) IEC JWG 69 Li TC21/SC 21A/TC69, "lithium for automobile/automotive applications". A standard developed by them is IEC 62660-2:2010, "secondary lithium-ion cells for the propulsion of electric road vehicles" [87], which describes the testing procedure to identify the reliability and abuse behaviour of the secondary lithium-ion cells that are used in EVs as well as in hybrid electric vehicles (HEVs) and battery electric vehicles (BEVs) [85,87,88].

Society of Automotive Engineers International (SAE): SAE is a USA based association and is a global association. SAE has more than 128,000 engineers and technical experts in the fields of automotive, commercial-vehicle and aerospace. Some of the TCs are, (a) Vehicle Battery Standards Steering, (b) Hybrid-EV Steering, (c) Battery Safety Standards, (d) Battery Standards Testing, (e) Battery Standards Recycling (f) Secondary Battery Use. One of the standards developed by such TCs is SAE J2464:2009 electric and hybrid electric vehicle rechargeable energy storage system (RESS) Safety and Abuse Testing [89]. It defines numerous tests, that are used to carry out the abuse testing of EVs, HEVs, and RESS, to identify the response of electrical energy storage and control systems to the incidents and situations that are outside their normal operating range [89]. Abuse test procedures detailed in this report comprise of a wide range of vehicle applications, including information related to electrical energy storage devices, RESS cells (batteries or capacitors), modules, and packs.

\subsubsection{National}

Standardization Administration of China (SAC): SAC makes standards for EV manufacturers, traction battery companies, electric machine companies, electric motorcycle companies, and areas such as passive safety of EVs in the countries such as Canada, Japan, Korea, and Germany. An exemplary TC is SAC/TC114/SC27 National Technical Committee of Auto Standardization Subcommittee Electric Vehicle and one of the standards developed is GB/T 31485-2015:2015, "safety requirements and test methods for traction battery of electric vehicle" [40]. This Standard specifies the safety requirements, testing methods, and inspection rules of traction batteries intended for EVs [90].

The United States Department of Energy (DoE): DoE mainly deals with the development of manuals for battery durability assessment. A list of manuals and their detailed description can be found in the technical report prepared by the Joint Research Centre (JRC) [91]. For the development of such manuals, DoE deals with organisations such as the United States Advanced Battery Consortium (USABC), Argonne National Laboratory (ANL), Idaho National Engineering Laboratory (INEL), Idaho National Engineering and Environmental Laboratory (INEEL), and Sandia National Laboratory (SNL). One of the standards developed under DoE with guidance by Sandia National Laboratories for the United States Department of Energy's National Nuclear Security Administration is FreedomCAR:2006 Electrical Energy Storage System (EESS) Abuse Test Manual for Electric and Hybrid Electric Vehicle Applications [92]. The scope of this standard is to define tests that are used for abuse testing of, EESS for EV and HEV applications. This testing determines the response of a given EESS design based on a variety of test conditions [92].

\subsection{Regulations}

Regulations are the comprehensive set of instructions that helps to ensure uniform implementation of laws and hence are also regularly known as rules or administrative laws, i.e., they have the force of law which makes their implementation obligatory [93]. A detailed definition of regulation and information regarding how the regulations are made is explained by the International Light Transportation Vehicle Association (ILTVA) at [94].

\subsubsection{European}

European Chemical Agency (ECHA): The main purpose of the ECHA is the safe use of chemicals in a variety of applications such as EV batteries, i.e., regulates the chemicals and biocides usage in the EU market. It processes chemical related files from the industry and 
examines them to see if they comply with legislation. Together with the European Union national governments, it focuses on the most hazardous substances and undertakes analysis on the cases where further risk management might be needed to protect people and the environment. Depending on the risk identified from chemicals, it takes its own decisions, and in some cases, it provides opinions and advice to help the European Commission make the correct decision [95]. Exemplary regulations developed by ECHA are, (a) Regulation on the Registration, Evaluation, Authorisation and Restriction of Chemicals (REACH) [96], and (b) the Battery Directive [97].

\subsubsection{International}

United Nations Economic Commission for Europe (UNECE): It was formed in the year 1947 by The United Nations Economic and Social Council (ECOSOC). It includes fifty-six member States in Europe, North America, and Asia. The regulations developed are UNECE R100, battery electric vehicle safety [98] and encompasses the variety of safety tests such as mechanical, fire, thermal, mechanical, vibration and shock (UNECE, 2019); and GTR 20, "Global Technical Regulation on the Electric Vehicle Safety (EVS)" [27].

\subsubsection{National}

National Highway Traffic Safety Administration (NHTSA): It legalizes the safety of vehicles and related equipment's, i.e., which includes EVs and their batteries in the United States (US). The agency enforces vehicle performance standards with the help of state and local governments to reduce injuries, deaths, and economic loss from vehicle crashes. It issues the Federal Motor Vehicle Safety Standards (FMVSS) to implement laws from the government $[70,99]$. One of the laws administrated by the NHTSA is the Motor Safety Vehicle, to save people from the risk of injuries or death happening due to design, construction and performance of vehicle [100].

\section{Abuse Testing: Crush Test}

While introducing EVs in the market, the manufacturers must show that the vehicle and its components match the safety limits assigned by the regulatory bodies. The battery is one of such components that is considered as a primary source of hazard for EV consumers [101] and hence, it needs to undergo rigorous safety tests before introducing EVs into the market [102]. Standards are usually considered as good practice documents. If the standard is not followed then the product manufacturer should justify the different route chosen [103].

It is important to note that standards encompass a variety of aims and objectives. A specific standard can have the combination of many objectives such as design, performance test, safety design, safety test, environmental protection, classification, and recommendation [103]. For example, FreedomCAR:2006 [92] and SAE J2464:2009 [89] help to investigate and gather the battery response under severe conditions, i.e., outside the normal operating range, for manufacturers to examine the battery system design failure. On the other hand, standards such as ISO 12405-3:2014 [84] and IEC 62660-2:2010 [87] provide the detailed test procedure to observe the reliability of the battery and also specifies the acceptable safety requirements.

Figure 1 provides an overview of the standard abuse tests, categorised as per the nature of the test conducted and misuse (electrical, chemical, thermal and mechanical). The tests are conducted either on the cell, module, or pack level depending on the respective standard or regulation. Underwriter laboratories have detailed information on each of these abuse tests [104]. The crash/crush test was marked green as this article focuses on this test. 


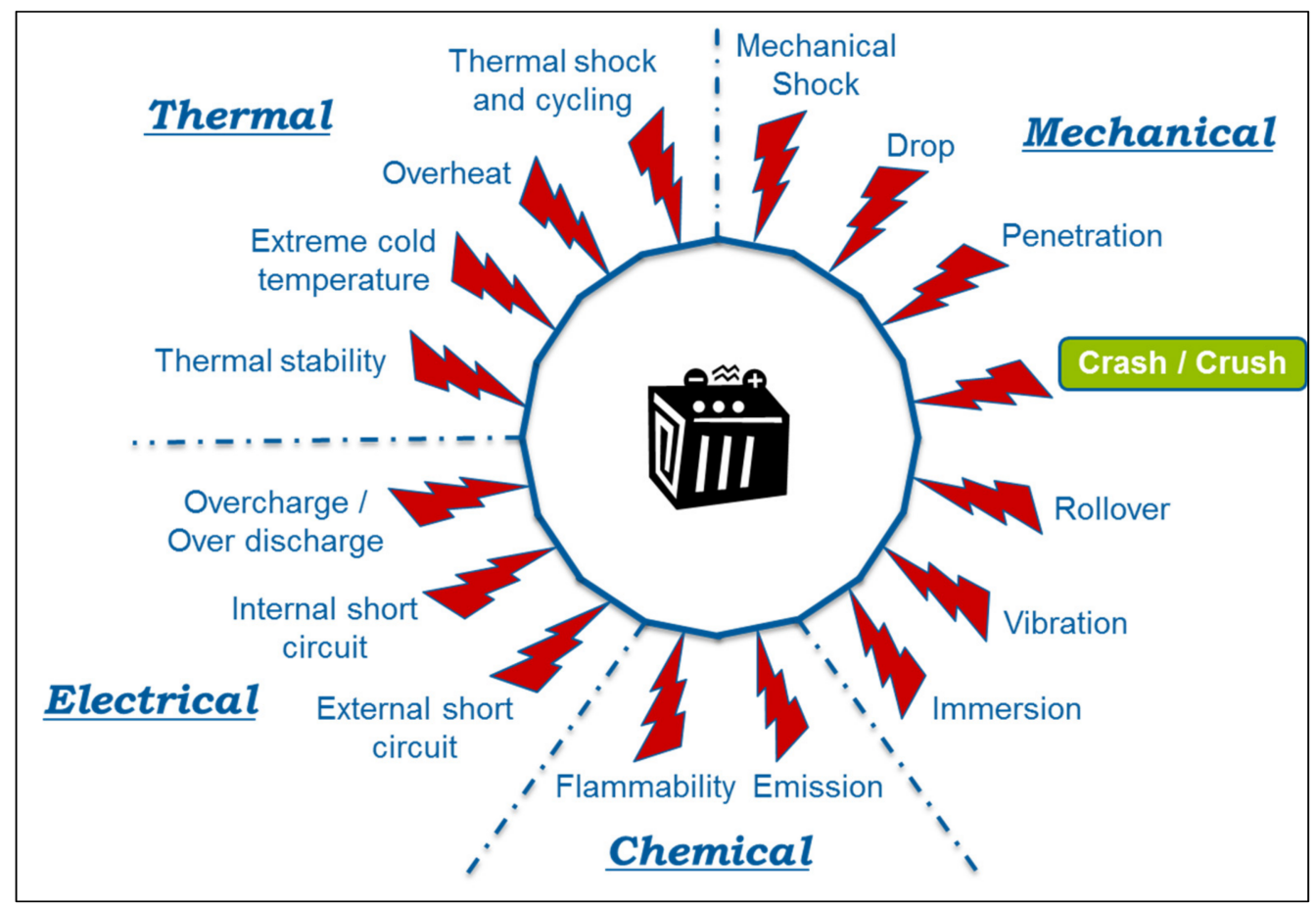

Figure 1. Abuse tests for the battery as per different standards and regulations [73].

Despite having such a wide variety of abuse tests, EV batteries might catch fire after an accident, i.e., either immediately or erstwhile [22,105]. It was forecasted by Machuca et al. that such incidents can go up to 135,000 vehicles/year by the year 2030 [14]. The detailed information on battery incidents and handling such incidents are elaborated by [106]. Considering this forecast and the number/examples of accidents that have happened so far, it can be said that the crush test should be paid more attention and should be investigated in depth [22]. Therefore, from here onwards, this research investigates the crush test and its relevant parameters. The standards and the regulations selected are, SAE J2464:2009 [89], GB/T 31485-2015:2015 [90], FreedomCAR:2006 [92], ISO 12405-3:2014 [84], IEC 62662-2:2010 [87], SAND2017-6925:2017 [107], UN/ECE-R100.02:2013 [98] and, GTR 20:2018 [108] as these are followed by more than fifty countries.

\subsection{Procedure}

There are numerous battery testing standards and regulations in the market that helps the manufacturer to design the battery system and introduce them in the market. The testing methods described in these standards and regulations help in accessing the performance and safety of the battery system but are not always pertinent.

The general procedure to carry out a crush test on a test device (TD), i.e., cell, module, or pack is to place it on an electrically isolated plate/support and then apply a specific crushing force by using a textured movable plate known as a crusher. However, it is worthwhile to note that the testing conditions differ in each standard and regulation. For example, SAE J2464:2009 [89] set the condition that the TD should be crushed until the initial dimension of TD reduces to $85 \%$, then hold it there for $5 \mathrm{~min}$, followed by a crush until its initial dimension reduces to $50 \%$, or until the force reaches $1000 \times$ weight of TD, while GB/T 31485-2015:2015 [90] states that the TD, i.e., cell voltage falls to $0 \mathrm{~V}$ or the deformation and force reaches $30 \%$ and $200 \mathrm{kN}$ (refer Table 2). Similarly, the TD (module and pack) should be crushed until one of the following conditions occur, (a) the TD reaches $70 \%$ of the initial dimension, or (b) the crushing force reaches $1000 \times$ weight of TD, or a specific unit as per Table 3, whichever is higher. 
Table 2. Test stop criteria as per different standards and regulations.

\begin{tabular}{|c|c|}
\hline Standards (Std.) and Regulations (Reg.) & $\begin{array}{c}\text { Procedure: Stop Criteria } \\
(C=\text { Cell; } M=\text { Module; } P=\text { Pack })\end{array}$ \\
\hline SAE J2464:2009 (Std.) & $\begin{aligned} \text { force }=1000 \times & \text { Test Device }(\mathrm{TD}) \text { weight } \\
& (\mathrm{C} / \mathrm{M} / \mathrm{P})\end{aligned}$ \\
\hline ISO 12405-3:2014 (Std.) & $100 \mathrm{kN}<$ force $<105 \mathrm{kN}^{1}(\mathrm{P})$ \\
\hline IEC 62660-2:2010 (Std.) & $\begin{array}{l}\text { voltage }=\text { abrupt voltage drop of one-third of } \\
\text { the original cell voltage or deformation } \geq 15 \% \\
\text { or force }=1000 \times \text { TD weight }(C)\end{array}$ \\
\hline FreedomCAR:2006 (Std.) & $\begin{array}{c}\text { deformation }=50 \% \text { or force }=1000 \times \text { TD } \\
\text { weight }(\mathrm{C} / \mathrm{M} / \mathrm{P})\end{array}$ \\
\hline SAND2017-6925:2017 (Std.) & $\begin{array}{c}\text { Force }=25 \mathrm{kN} \text { or } \mathrm{HSL} \geq 5 \text { or impactor reached } \\
100 \% \text { practical displacement }(\mathrm{C}) \\
\text { HSL } \geq 5 \text { or impactor reached } 100 \% \text { practical } \\
\text { displacement }(\mathrm{M} / \mathrm{P})\end{array}$ \\
\hline GB/T 31485-2015:2015 (Std.) & $\begin{array}{c}\text { voltage }=0 \mathrm{~V} \text { or deformation }=30 \% \text { or force }= \\
\qquad 200 \mathrm{kN}(\mathrm{C}) \\
\text { deformation }=30 \% \text { or force }=1000 \times \mathrm{TD} \\
\text { weight or force as per Table } 3 \text { whichever is } \\
\text { higher }(\mathrm{M} / \mathrm{P})\end{array}$ \\
\hline UN/ECE-R100.02:2013 (Reg.) & $100 \mathrm{kN}<$ force $<105 \mathrm{kN}^{2}(\mathrm{M} / \mathrm{P})$ \\
\hline GTR 20:2018 (Reg.) & $100 \mathrm{kN}<$ force $<105 \mathrm{kN}^{2}(\mathrm{M} / \mathrm{P})$ \\
\hline
\end{tabular}

${ }^{1}$ Customer determined value can be used based on predicted forces from vehicle crash test [84]. ${ }^{2} \mathrm{~A}$ higher crush force may be applied on the basis of the manufacturers' request [98].

Table 3. Crush force as per GB/T 31485-2015:2015 [90].

\begin{tabular}{cc}
\hline $\begin{array}{c}\text { Number of Cells Contacted by the Crushing } \\
\text { Surface (n) }\end{array}$ & Crush Force (kN) \\
\hline 1 & 200 \\
$2-5$ & $100 \times \mathrm{n}$ \\
$>5$ & 500 \\
\hline
\end{tabular}

According to FreedomCAR:2006 [92], the TD must be crushed to $85 \%$ of its initial height and then be on hold for $5 \mathrm{~min}$, followed by further crushing of the TD until $50 \%$ of its initial height or until the force becomes 1000 times the TDs mass [109]. While as per UN/ECE-R100.02:2013 [98], the TD is crushed until the minimum force of $100 \mathrm{kN}$, but not more than $105 \mathrm{kN}$, and the acceptance criteria are that the TD should not catch fire, explode or show signs of electrolyte leakage. Similarly, GTR 20:2018 also states that the crushing force shall be between $100 \mathrm{kN}$ to $105 \mathrm{kN}$ [108].

The amount of force required, as per ISO 12405-3:2014 [84] is similar to UN/ECER100.02:2013 [98] and is within the range of $100 \mathrm{kN}$ to $105 \mathrm{kN}$. However, in ISO 124053:2014 [84], the manufacturers can test as per the force expected during a vehicle crash, while UN/ECE-R100.02:2013 [98] approves testing only at a higher crush force, at the request of the manufacturers. SAND2017-6925:2017 [107] specifies that the cells should be crushed until the specified conditions are met, (a) the force reaches the limit of $25 \mathrm{kN}$, (b) the impactor reaches $100 \%$ deformation and the hazard safety level (HSL) is greater than or equal to 5. For module and pack testing, the criteria are the same except that nothing is specified in regards to force.

In terms of IEC 62660-2:2010 [87], the test is continued until the voltage drop of onethird of the initial cell voltage or the crushing force is $1000 \times$ weight of TD. If the TD is deformed $15 \%$ or more of its initial dimension, before the above condition occurs, then the force should be released. 


\subsection{Crush Speed}

The crushing speed is one of the important factors that is historically used to investigate the mechanical deformation of the battery, which consequently determines the short circuit range. Joshua Lamb et al. showed that as the crushing speed changes the value of force required for cell failure and the intrusion within the cell for failure changes as well [110]. They demonstrated that for the speed of $0.1 \mathrm{~mm} / \mathrm{s}$ the force and intrusion required for failure were around $45 \mathrm{kN}$ and $4.5 \mathrm{~mm}$, while for $10 \mathrm{~mm} / \mathrm{s}$ it was $50 \mathrm{kN}$ and more than $5.5 \mathrm{~mm}$ [110]. Hu et al. also concluded that the crushing speed has a significant influence on the failure behaviour of the batteries [111]. The difference in the crushing speed that can be seen in the standards and regulations is thus of great importance. For cell level testing, SAE J2464:2009 [89] recommends the speed from $0.5 \mathrm{~mm} / \mathrm{min}$ to $1 \mathrm{~mm} / \mathrm{min}$, while SAND2017-6925:2017 [107] and GB/T 31485-2015:2015 [90] recommends at $1 \mathrm{~mm} / \mathrm{min}$ and $300 \pm 60 \mathrm{~mm} / \mathrm{min}$, respectively. This recommendation by SAND2017-6925:2017 [107] and GB/T 31485-2015:2015 [90] stays the same for module and pack level testing as well. However, SAEJ2464:2009 [89] suggests that for the module and pack level, the impactor speed should be $5 \mathrm{~mm} / \mathrm{min}$ to $10 \mathrm{~mm} / \mathrm{min}$. Henceforth, it can be noticed that there is a drastic speed difference at module and pack level for all three standards. It is also worth noticing here that ISO 12405-3:2014 [84], IEC 62660-2:2010 [87], FreedomCAR:2006 [92], UN/ECE-R100.02:2013 [98] and, GTR 20:2018 [108] do not mention anything about the impactor speed (refer Table 4).

Table 4. Crush speed as per different standards and regulations.

\begin{tabular}{cc}
\hline Standards and Regulations & $\begin{array}{c}\text { Crush Speed (mm/min) } \\
(\mathbf{C}=\mathbf{C e l l} \mathbf{~} \mathbf{M}=\mathbf{\text { Module}} \mathbf{P}=\mathbf{P a c k})\end{array}$ \\
\hline SAE J2464:2009 [39] & $0.5-1(\mathrm{C}) 5-10(\mathrm{M} / \mathrm{P})$ \\
ISO 12405-3:2014 [42] & Not mentioned \\
IEC 62660-2:2010 [43] & Not mentioned \\
FreedomCAR:2006 [41] & Not mentioned \\
SAND2017-6925:2017 & $1(\mathrm{C} / \mathrm{M} / \mathrm{P})$ \\
GB/T 31485-2015:2015 [40] & $300 \pm 60(\mathrm{C} / \mathrm{M} / \mathrm{P})$ \\
UN/ECE-R100.02:2013 [44] & Not mentioned \\
GTR 20:2018 & Not mentioned \\
\hline
\end{tabular}

\subsection{State of Charge (SoC)}

According to Wang et al. the $\mathrm{SoC}$ has a significant effect on the volume of the cellactive particle and mechanical properties and their value changes depending on $\mathrm{SoC}$; thus, understanding SoC-based mechanical behaviour of LIB cells becomes crucial [23]. From Table 5 it can be seen that the SoC level (100\% of TD) is the same for SAE J2464:2009 [89], FreedomCAR:2006 [92], SAND2017-6925:2017 [107], and GB/T 31485-2015:2015 [90], but UN/ECE-R100.02:2013 [98], ISO 12405-3:2014 [84] and IEC 62660-2:2010 [87] have their own specific criteria. For example, as per UN/ECE-R100.02:2013 [98], the SoC should not be in the lower $50 \%$ of the normal operating range of the TD, which is also recommended by ISO 12405-3:2014 [84] for high power (HP) application. However, for high energy (HE) application, ISO 12405-3:2014 [84] suggests that the SoC should be taken as the maximum $\mathrm{SoC}$ of the normal operation. In IEC 62660-2:2010 [87] the SoC requirement is categorized based on vehicle type, i.e., for BEVs SoC should be $100 \%$, while for HEVs it should be $80 \%$. GTR 20:2018 [108] states that the TD shall be charged to 100\% SoC. 
Table 5. SoC level as per different standards and regulations.

\begin{tabular}{cc}
\hline Standards and Regulations & $\begin{array}{c}\text { SoC }(\mathbf{\%}) \\
(\mathbf{C}=\text { Cell; } \mathbf{M}=\mathbf{\text { Module; }} \mathbf{P}=\mathbf{\text { Pack}})\end{array}$ \\
\hline SAE J2464:2009 & $100(\mathrm{C} / \mathrm{M} / \mathrm{P})$ \\
ISO 12405-3:2014 & $\geq 50\left(\begin{array}{c}\text { High Power), max. SoC at normal operation } \\
\text { (High Energy) }(\mathrm{P})\end{array}\right.$ \\
IEC 62660-2:2010 & $100(\mathrm{BEVs})$ \\
FreedomCAR:2006 & $80(\mathrm{HEVs})(\mathrm{C})$ \\
SAND2017-6925:2017 & $100(\mathrm{C} / \mathrm{M} / \mathrm{P})$ \\
GB/T 31485-2015:2015 & $100(\mathrm{C} / \mathrm{M} / \mathrm{P})$ \\
UN/ECE-R100.02:2013 & $100(\mathrm{C} / \mathrm{M} / \mathrm{P})$ \\
GTR 20:2018 & $100(\mathrm{M} / \mathrm{P})$ \\
\hline
\end{tabular}

\subsection{Press Position}

Press position is significantly one of the important parameters that need to be considered while testing the cells, module, or pack. The exponent conducted the crush test at different orientations (perpendicular to electrode surfaces, electrode edges, etc.) and exhibited diversity in the results for the distinctive orientation [112]. Hence, it can be said that examining the multiple press position is important during battery testing.

Based on the analysis of the selected standards and regulations, it is found that SAE J2464:2009 [89] and FreedomCAR:2006 [92] only state that the test should be performed at a vulnerable location.

UN/ECE-R100.02:2013 [98] and GTR 20:2018 [108] allows the manufacturers and technical services to agree upon the plate position by taking into account the TDs travel direction relative to its installation in the vehicle. The force needs to be applied perpendicular and horizontally to the direction of travel of the rechargeable energy storage system (REESS) [113].

GB/T 31485-2015:2015 [90] for cell crush testing requires to "apply load in the direction perpendicular to the polar plate of battery"; however, the polar plates are not clearly identified or explained in the standard and a figure for the guidance is available such as Figure 2. For module crush testing, the direction of crush should be the "same as the direction where the battery module is most highly susceptible to crushing on the layout of the whole vehicle. If the direction where the battery module is most highly susceptible to crushing is not available, then pressure shall be exerted vertically to the arrangement direction of secondary cells" (refer Figure 3).
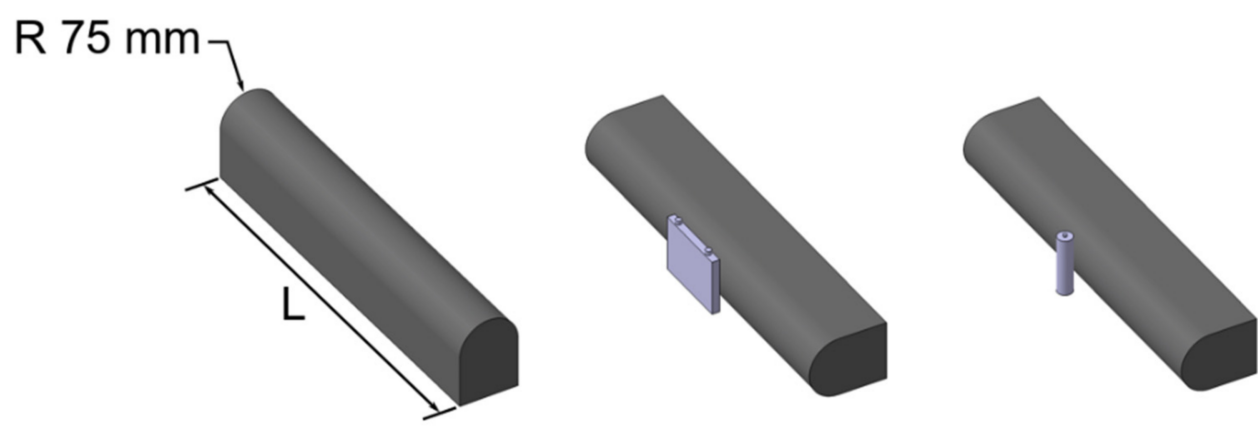

Figure 2. Cell crush board as per GB/T 31485-2015:2015 [40]. 

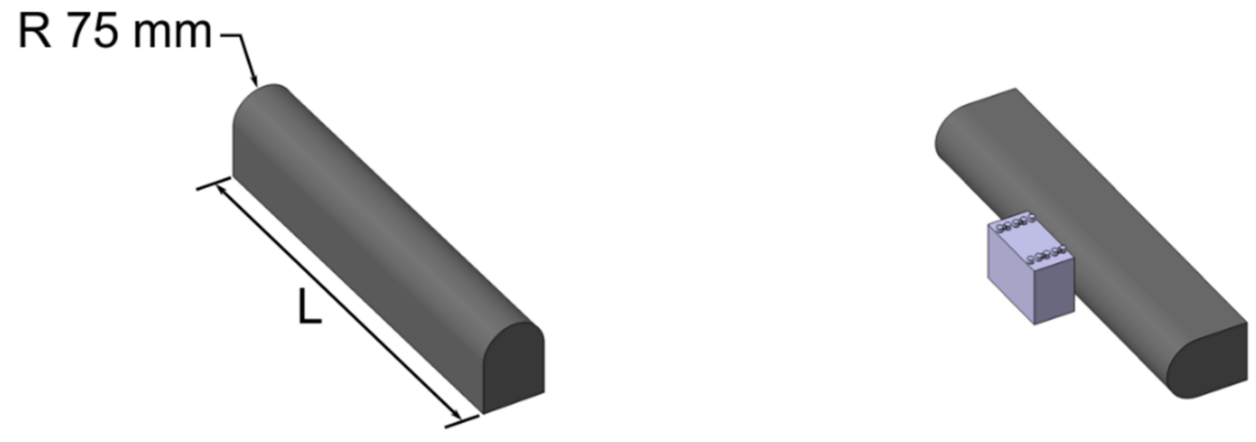

Figure 3. Module crush board as per GB/T 31485-2015:2015 [40].

According to IEC 62660-2:2010 [87], the cell's positive and negative electrodes are faced perpendicularly to the crushing force. As per ISO 12405-3:2014 [84], the battery is oriented similarly as it is positioned in the vehicle and the impactors' cylinder axis is arranged vertically to the battery. The centre of the impactor must be aligned with the centre of the TDs projected plane, that is, perpendicular to the direction of the crush.

As per SAND2017-6925:2017 [107], the module and pack are crushed between the impactor and the flat plate at the most vulnerable location. The cylindrical cells are crushed along the transverse axis. The prismatic and pouch cells are crushed in Y-and Z-orientation (refer Figure 4). The Y-orientation depicts the crush direction into the positive and negative terminal and the Z-orientation depicts crushing perpendicular to the terminals. The cell is crushed in a fixture that mechanically supports the cell and replicates the constrained cell within the module (refer Figure 5). The crush in X-orientation should be performed like the module and pack testing.

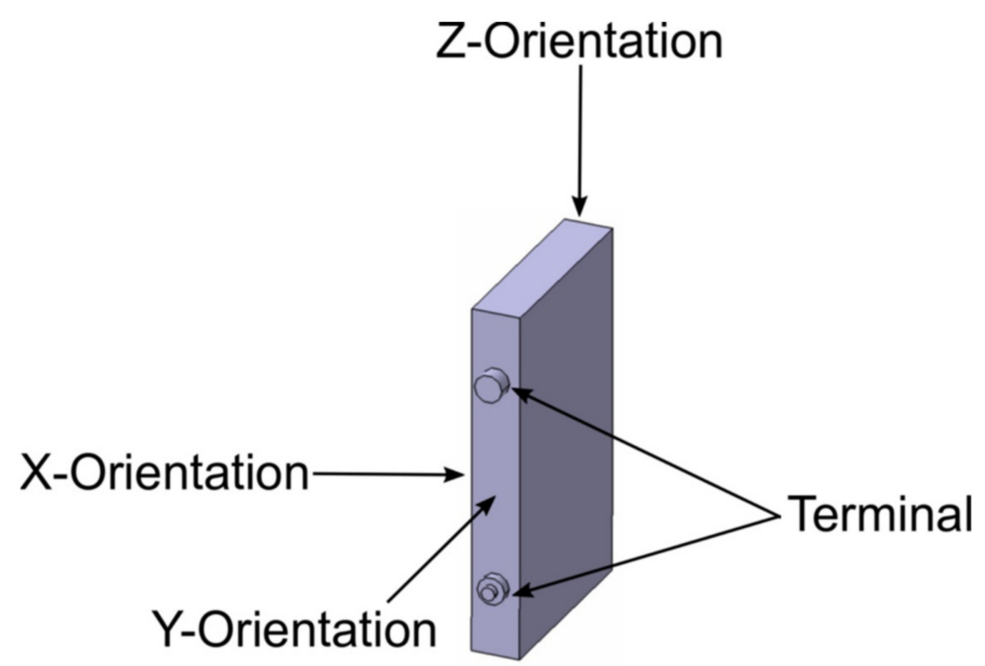

Figure 4. X-, Y- and Z-orientation of prismatic cell as per SAND2017-6925:2017 [107]. 


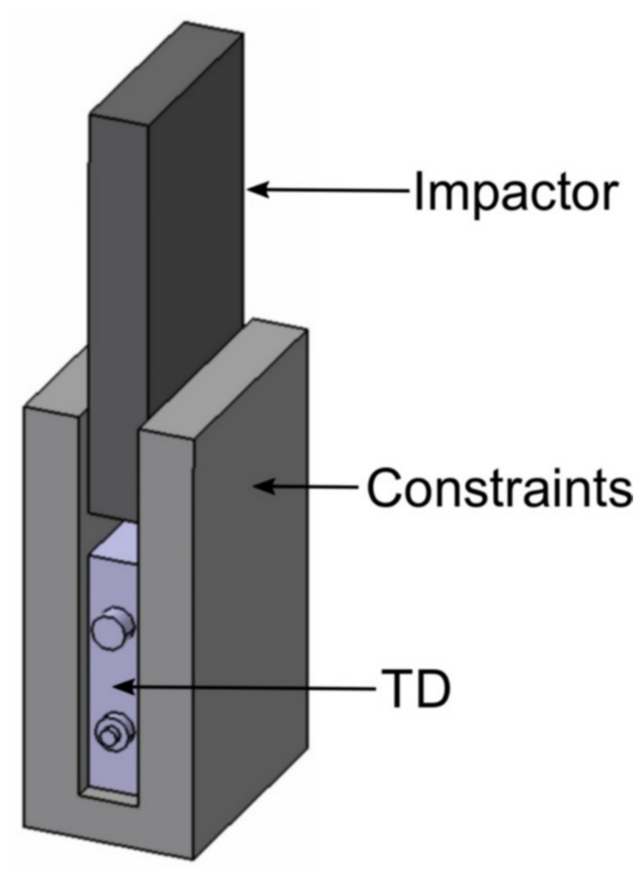

Figure 5. Prismatic cell in the fixture and crushed along Z-orientation as per SAND20176925:2017 [107].

\subsection{Crusher Shape and Dimensions}

As per the experimental research conducted by Li et al. on the cells, the outcome found was that the smaller the diameter of the hemispherical impactor/punch, the earlier is the start of the internal short circuit [33]. It was also recorded that the relative intrusion at the beginning of the internal short circuit was highest for a $24 \mathrm{~mm}$ diameter hemisphere followed by $12 \mathrm{~mm}$ and $6 \mathrm{~mm}$ for pouch cells ( 20 Ah commercial lithium iron phosphate (LFP) pouch cell, i.e., $\mathrm{L}=8.27 \mathrm{in}, \mathrm{W}=4.33$ in, $\mathrm{T}=0.45 \mathrm{in}$ ). Likewise, Sahraei et al. observed a similar trend during the experiments with hemispherical punches of the diameters of $44.45 \mathrm{~mm}, 28.575 \mathrm{~mm}$, and $12.7 \mathrm{~mm}$. They also concluded that, as the size of the crusher increases, the force value increases for the same amount of intrusion [114]. The cells used were small (740 mAh of $\mathrm{L}=2.34 \mathrm{in}, \mathrm{W}=1.34 \mathrm{in}, \mathrm{T}=0.21 \mathrm{in}$ ), medium ( $3.2 \mathrm{Ah}$ of $\mathrm{L}=5.10 \mathrm{in}$, $\mathrm{W}=1.71 \mathrm{in}, \mathrm{T}=0.32 \mathrm{in}$ ) and large (19.5 Ah of $\mathrm{L}=8.94 \mathrm{in}, \mathrm{W}=6.30 \mathrm{in}, \mathrm{T}=0.29 \mathrm{in}$ ) pouch cells [114].

As per the selected standards and regulations, to crush the battery module and pack, the shape/design of the impactor (also known as crush plate or textured plate) remains constant for UN/ECE-R100.02:2013 [98], SAE J2464:2009 [89], ISO 12405-3:2014 [84], GTR 20:2018 [108] and FreedomCAR:2006 [92] (refer Figure 6). However, the dimension of the plate, i.e., diameter of the semi-cylinder and the length (L), width (W), and height $(\mathrm{H})$ of the plate vary as per each standard and the regulation. 


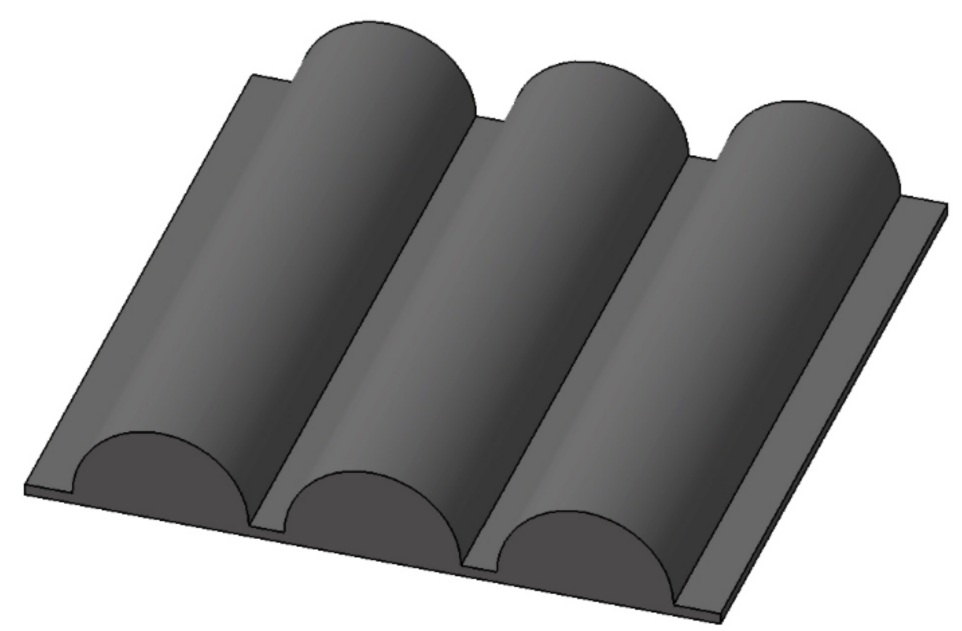

Figure 6. Crush plate for module as per UN/ECE-R100.02:2013 [98], GTR 20:2018 [108], SAE J2464:2009 [89], ISO 12405-3:2014 [84], and FreedomCAR:2006 [92].

For example, UN/ECE-R100.02:2013 [98] and GTR 20:2018 [108] specifies that the radius of the semi-cylinder should be $75 \mathrm{~mm}$ with a spacing of $30 \mathrm{~mm}$ between each semi-cylinder and the overall plate size should not exceed $600 \times 600 \mathrm{~mm}$. While, FreedomCAR:2006 [92] states the same for the semi-cylinders' dimensions, but does not mention anything about the size of the plate. For ISO 12405-3:2014 [84], the semi-cylinder length should be more than the edge of TD by a minimum of $50 \mathrm{~mm}$ on each side. SAE J2464:2009 [89] requires the diameter of the semi-cylinder to be equivalent to the smallest dimension of the TD and the number of semi-cylinders including the spacing between them must be enough to cover the whole span of the area of TD where the short circuit can occur. GB/T 31485-2015:2015 [90] specifies that the semi-cylinder must have a $75 \mathrm{~mm}$ radius $(\mathrm{R})$ and the length of the impactor must be greater than the size of the TD (refer Figure 3) but not more than $1 \mathrm{~m}$. On the other hand, IEC 62660-2:2010 [87] does not specify any information about the battery module or pack testing, i.e., it only provides information about cell testing. SAND 2017-6925:2017 [107] specifies that the crusher plate should have only a single semi-cylindrical impactor of $75 \mathrm{~mm}$ radius and must be located at the centre of the plate as represented in Figure 7.

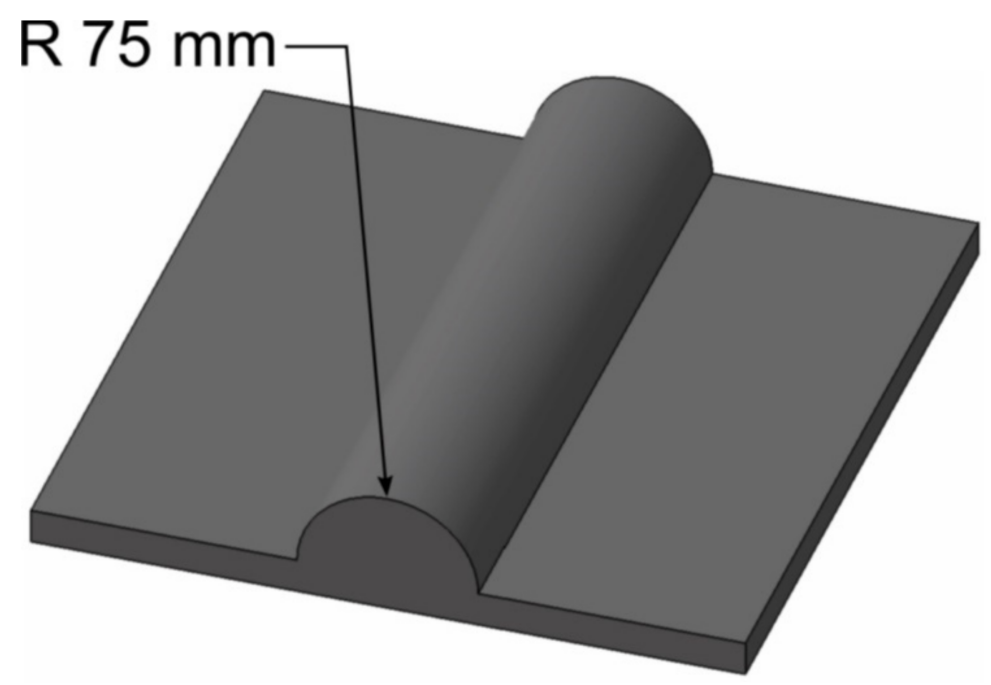

Figure 7. Crush plate for the module as per SAND2017-6925:2017 [107].

For cell testing, GB/T 31485-2015:2015 [90] specifies that the semi-cylindrical impactor should have a radius of $75 \mathrm{~mm}$ and the length should be more than the dimension of the cell (see Figure 2), while FreedomCAR:2006 [92] and SAE J2464:2009 [89], state that 
the dimension of the cylindrical impactor should be equivalent to half of the TD average diameter or the diameter of the cells respectively (refer Figure 8). IEC 62660-2:2010 [87] recommends crushing the prismatic cell and cylindrical cell with a spherical or hemispherical impactor (refer Figure 9) and a round impactor (refer Figure 8) of $75 \mathrm{~mm}$ radius. As per SAND 2017-6925:2017 [107], cylindrical cells shall be crushed using the impactor (refer Figure 8) of diameter as stated in Table 6. The prismatic and pouch cells are crushed using the impactor having a semi-circular shape with a rectangular base (refer Figure 10). The diameter of the semi-circle must be decided based on the cell width as mentioned in Table 7. The length and width of the impactor used for crush is equal to the length and width of TD respectively and height shall be adequate to achieve 100\% intrusion within TD. However, UN/ECE-R100.02:2013 [98] and ISO 12405-3:2014 [84] do not specify anything regarding the shape and size of the impactor used for the cell crush test.

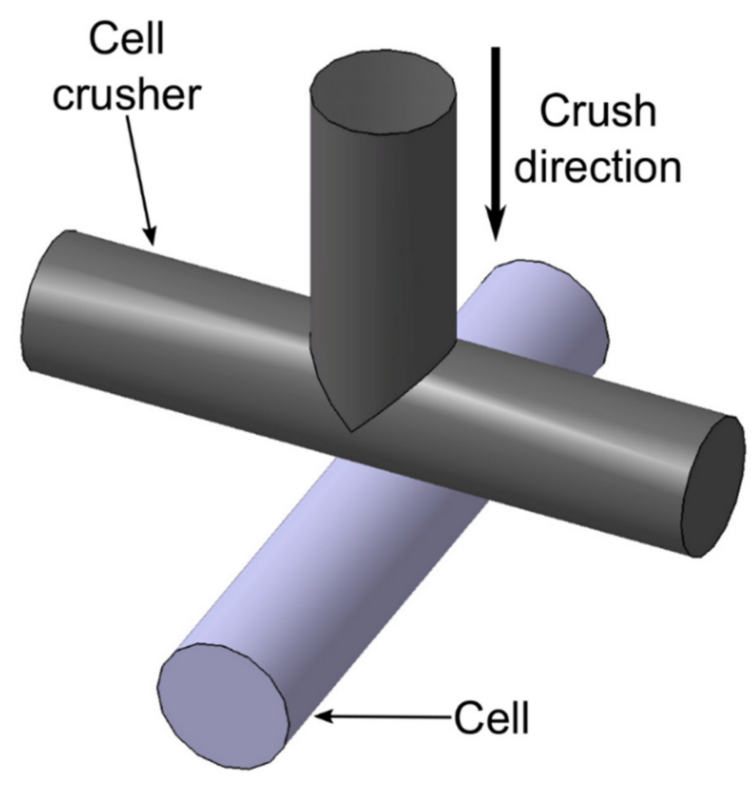

Figure 8. Cell crusher as per SAE J2464:2009 [89], FreedomCAR:2006 [92], IEC 62660-2:2010 [87], and SAND2017-6925:2017 [107].

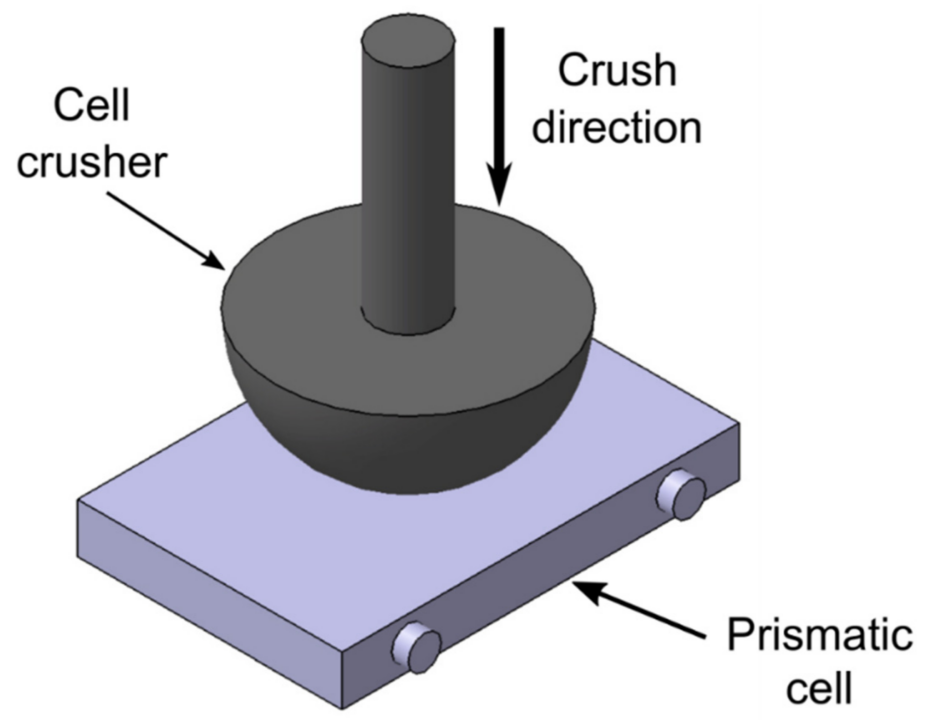

Figure 9. Cell crusher for prismatic cells as per IEC 62660-2:2010 [87]. 
Table 6. Recommended impactor diameter for crushing cylindrical cells as per SAND20176925:2017 [107].

\begin{tabular}{cc}
\hline Impactor Diameter $(\mathbf{m m})$ & Cell Diameter $(\mathbf{m m})$ \\
\hline 20 & Up to 32 \\
30 & $32-60$ \\
60 & $>60$ \\
\hline
\end{tabular}

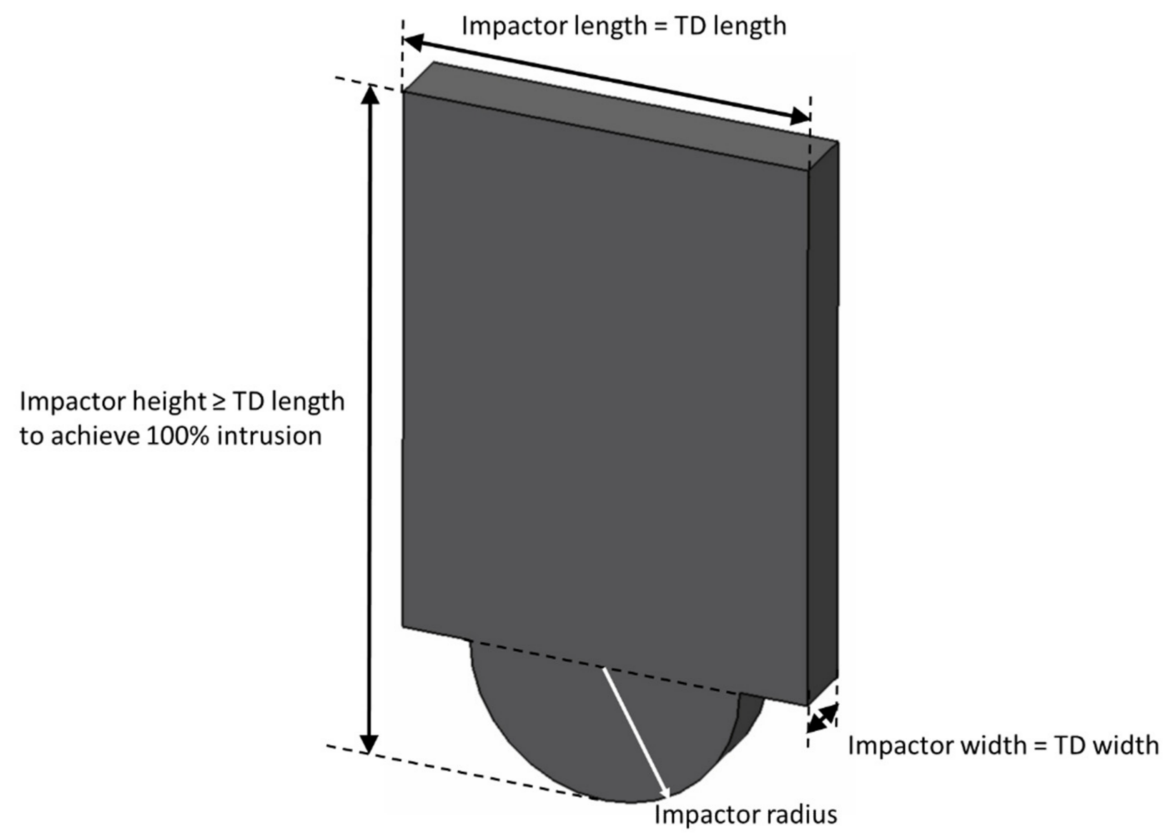

Figure 10. Impactor for crushing prismatic and pouch cell as per SAND2017-6925:2017 [107].

Table 7. Recommended impactor diameter for crushing prismatic and pouch cells as per SAND20176925:2017 [107].

\begin{tabular}{cc}
\hline Impactor Diameter $(\mathbf{m m})$ & Cell Width $(\mathbf{m m})^{\text {a }}$ \\
\hline 20 & Up to 32 \\
30 & $32-60$ \\
60 & $60-150$ \\
150 & $>150^{\mathrm{b}}$
\end{tabular}

a Width of the surface that is being crushed by the impactor. ${ }^{b}$ Semi-cylinder radius of $75 \mathrm{~mm}$ (150 mm diameter) is used to scale it with the pack crush.

\subsection{Number of Testing Samples}

Battery testing is an expensive process because once a crush test is performed on a TD, they are not allowed to be used for another testing [115]. In the case of SAE J2464:2009 [89], it is mentioned that the TD should be tested for at least two different axes (out of three axes, X, Y and Z) using a different TD for each test. While, FreedomCAR:2006 [92] states that at least one TD needs to be tested and if more TDs are available, then the testing should be performed at multiple axes, and crushing without containment boxes is recommended. GB/T 31485-2015:2015 [90] states that two samples must be tested for cells and one sample in case of module and pack. However, SAND2017-6925:2017 [107] states that four cells and two modules or packs should all be tested. According to ISO 12405-3:2014 [84], the crush axes should be based on a vehicle's crash test mentioned in the regional and national regulations and as specified by the manufacturers. However, if the regulations are missing, then the axes need to be defined by the manufacturers. However, UN/ECER100.02:2013 [98], IEC 62660-2:2010 [87] and GTR 20:2018 [108] do not specify the number of samples to be tested (refer Table 8). 
Table 8. Minimum number of samples needs to be tested as per different standards and regulations.

\begin{tabular}{|c|c|}
\hline Standards and Regulations & $\begin{array}{l}\text { Minimum Number of Samples } \\
(C=\text { Cell; } M=\text { Module; } P=\text { Pack })\end{array}$ \\
\hline SAE J2464:2009 & $\begin{array}{c}2(\mathrm{C})^{1} \\
1(\mathrm{M} / \mathrm{P})^{1}\end{array}$ \\
\hline ISO 12405-3:2014 & Depends on vehicle crash tests $(\mathrm{P})$ \\
\hline IEC 62660-2:2010 & Not mentioned \\
\hline FreedomCAR:2006 & $1(\mathrm{C} / \mathrm{M} / \mathrm{P})$ \\
\hline SAND2017-6925:2017 & $\begin{array}{c}4(\mathrm{C}) \\
2(\mathrm{M} / \mathrm{P})\end{array}$ \\
\hline GB/T 31485-2015:2015 & $\begin{array}{c}2(\mathrm{C}) \\
1(\mathrm{M} / \mathrm{P})\end{array}$ \\
\hline UN/ECE-R100.02:2013 & Not mentioned \\
\hline GTR 20:2018 & Not mentioned \\
\hline
\end{tabular}

${ }^{1}$ Cell level: two tests per cell axis; pack level: one test per crush axis.

\section{Results and Discussion}

To ensure the safety of EVs and their batteries, various standards and regulations have been developed by regulatory bodies around the world. Manufacturers must follow the regulations before introducing the vehicles to the market. To attain the conditions mentioned in the regulations, manufacturers are recommended to follow the regional accepted standards. These standards can be such as FreedomCAR:2006 [92] and SAE J2464:2009 [89] which help them to investigate the battery system design and others such as ISO 12405-3:2014 [84] and IEC 62660-2:2010 [87] which provide the acceptable safety requirements. Both types of standards are very useful and can help to achieve a good level of safety.

Despite such supportive standards and rigorous regulations developed by the regulatory bodies, there were several incidents noticed in which EVs caught fire after accidents and possessed a high risk for consumers. Companies such as General Motors, BMW, and Audi had to recall their EVs from the market as there was a risk from the batteries installed in their respective car models. Therefore, the question to ponder is, whether the tests conducted are right and enough for EV batteries.

Similarly, another question to think about is the number of test samples during the approval of the battery, because the TD used once in testing cannot be reused for another test, which makes testing an expensive endeavour. For example, FreedomCAR:2006 [92] recommends having at least one sample, SAE J2464:2009 [89] recommends testing two samples, GB/T 31485-2015:2015 [40] states that there should be two samples for cell and one sample for a module and pack, while ISO 12405-3:2014 [84] states that the number of samples should be decided based on vehicle crash tests. Such ambiguity is challenging for manufacturers because this increases the cost of tests, subsequently increasing the cost of EVs and it does not reflect the certainty in terms of safety of the EV consumer. A similar situation of imprecise information is in the below-mentioned areas as well:

1. Procedure: The primary aspect of all the abuse tests is to define the stop criteria where the test limits are reached, and the testing can be stopped. After analysing the selected standards and regulations, it is found that there is a significant difference in the overall procedure as well as the criteria such as force, voltage, deformation, and HSL. For example, SAE J2464:2009 [89] has a simple procedure in which the formula is to multiply the weight of TD with the constant value of 1000 . The same formula is also adopted by FreedomCAR:2006 [92], but with an additional deformation parameter which is equal to 50\%. Comparing these with ISO 12405-3:2014 [84], UN/ECER100.02:2013 [98], and GTR 20:2018 [108], it is found that the force should be between $100 \mathrm{kN}$ and $105 \mathrm{kN}$ and does not consider the deformation. While on the other hand, IEC 62660-2:2010 [87] and GB/T 31485-2015:2015 [90] consider the voltage as an additional parameter to force and deformation. SAND 2017-6925:2017 [107] takes this one step further by providing HSL limits as well to stop the tests. 
Therefore, it can be said that there is some degree of commonality between standards such as SAE andFreedomCAR:2006, but when all the selected standards and regulations are compared with each other, it is fair to say that the manufacturers face challenges to decide which standard or regulation needs to be followed as they all have a variety of procedures and stop criteria parameters;

2. Crushing Speed: It is a well-known fact that the deformation of the cell differs from the battery module or pack. The failure of the battery module or pack is induced by the non-uniform deformation inside each cell that generates a vulnerable zone near the gap among cells. From Section 3.2 it can be seen that the standards and regulations differ significantly, as the impactor speed for cells ranges from $0.5 \mathrm{~mm} / \mathrm{min}$ as stated in the SAE J2464:2009 [89] to $360 \mathrm{~mm} / \mathrm{min}$ as per GB/T 31485-2015:2015 [90]. In terms of module and pack level testing, the impactor speed ranges from $1 \mathrm{~mm} / \mathrm{min}$ to $360 \mathrm{~mm} / \mathrm{min}$. On the other hand, some of the standards such as ISO 12405-3:2014 [84], IEC 62660-2:2010 [87] FreedomCAR:2006 [92], GTR 20:2018 [108] and, UN/ECER100.02:2013 [98] have not provided any information regarding the impactor speed. Moreover, all the standards and regulations are based on quasi-static testing (impactor is forced on the battery) and do not undertake the realistic dynamic situation where the EV carrying battery can crush with other vehicles, i.e., other vehicles can be compared with an impactor in such a situation. Under a quasi-static situation, homogeneous deformation can be noticed within the packed batteries and battery failure distribution is in a random pattern. Conversely, in the case of dynamic impact, row by row crushing of packed batteries can be observed with force concentrating at some certain rows that result in severe deterioration of the batteries under the equal crushing displacement, implicating higher failure risk. Based on the dynamic battery test, it was found that the crushing speed dominates the failure behaviour rather than crushing energy [111]. The failure displacement declines as the crushing speed exceed $1,200,000 \mathrm{~mm} / \mathrm{min}$. Kisters et al. also found that the crushing speed has a significant influence on the failure behaviour of the TD [116]. They experimentally evaluated that a high-speed crush test $(300,000 \mathrm{~mm} / \mathrm{min})$ has a double-stage failure process with an insignificant voltage drop before the load reaches its maximum and a radical voltage drop to almost $0 \mathrm{~V}$ at the maximum load, while a low-speed crush test $(6 \mathrm{~mm} / \mathrm{min})$ has a single-stage failure process with one sharp voltage drop to zero before reaching the maximum load.

Moreover, it is crucial to note that the absence of impactor crush speed value in some standards and regulations can yield inconclusive or discrepant results for quasi-static tests.

Henceforth, it can be said that the current standards and regulations need to be harmonised because (a) the currently available impactor crush speed values vary drastically from each other, as well as (b) the unavailability of these values in some standards and regulations can be inconclusive and cause discrepancy in the results. In addition, it is important to note that there is a need for a dynamic testing approach that resembles the real-time situation of the EV crash;

3. SoC: SoC performs a significant role in battery failure, hence, it becomes crucial to understand SoC-based mechanical behaviour while studying the crashworthiness of EV batteries, especially in the operation situation when the electrochemical cycle occurs and the SoC value is above zero [23]. Such differences in SoC values during the tests are of high relevance because Wang et al. found that the mechanical properties of a TD vary with its SoC [23]. Moreover, according to Wang et al. a TD faces mechanical hardening with an increase in SoC $[10,23]$, thus increasing the amount of force required to achieve the same intrusion. Sheikh and Wang et al. observed that at a higher SoC, the voltage drop occurs at lower levels of intrusion [23,117]. Despite the SoC value having such importance, it can be seen from Section 3.3. that the value is mostly recommended to be $100 \%$ during the tests. One of the standards and regulations such as ISO 12405-3:2014 [84] and UN/ECE-R100.02:2013 [98] have 
their conditions, though, it does not provide a variety of SoC values under which the battery should be tested. IEC 62660-2:2010 [87] categorizes SoC for testing based on the vehicle type (BEV and HEV) and does not consider the range of SoCs over which the batteries shall be tested.

Henceforth, evaluating the standards and regulations against the literature, it can be said that there is a need for tests that undertake a variety of SoC values while approving the EV battery, i.e., rather than just doing the test as per one value (100\% SoC);

4. Press position: Considering the press position while carrying out the crush test is of high importance. Maleki and Haward had carried out the research on various crush positions and demonstrated that the slight damage at the edge of the prismatic cell has a higher probability to lead to thermal runaway than crushing the cell at flat face [118]. The exponent observed similar behaviour during the testing. They represented that the mechanical deformation/damage at the edge of the cell has higher chances of thermal runaway compare with damage perpendicular to the electrode surface [112]. Thus, considering various press positions for testing becomes crucial.

The studies of the standards and regulations show that there is no clear information provided in terms of the exact location of the impactor that presses the cell, module, or pack, i.e., it can be anywhere, top, bottom, or centre (refer Figure 11). Moreover, some of the current standards such as SAE J2464:2009 [89], FreedomCAR:2006 [92], SAND2017-6925:2017 [107], and GB/T 31485-2015:2015 [90] are quite ambiguous as they only mention the "vulnerable" and "susceptible" position of the battery but do not define the position clearly. Similar ambiguity is noticed further in GB/T 314852015:2015 [90] in terms of polar plates which need to be considered while testing the cells, i.e., no description is provided about the polar plate.

Henceforth, it can be said that the information provided on the press position needs to be improved [113] and certainly the decision should not be left to the manufacturers and technical services as mentioned by UN/ECE-R100.02:2013 [98] and GTR 20:2018 [108]. Moreover, there should be some in-depth information considering cell, module, and pack level testing;

5. Crusher shape and dimensions: In terms of impactor shape/design, it was noticed that to test the battery module and pack, the shape of the impactor remains the same for GTR 20:2018 [108], FreedomCAR:2006 [92], SAE J2464:2009 [89], UN/ECER100.02:2013 [98] and ISO 12405-3:2014 [84], while SAND2017-6925:2017 [107] differs in terms of the number of semi-cylinders on the plate and IEC 62660-2:2010 [87] does not provide any such information. Though, it is worthwhile to note that IEC 62660-2:2010 [87] defines the shape/design of the impactor for a cylindrical cell which is similar to SAE J2464:2009 [89], SAND2017-6925:2017 [107], and FreedomCAR:2006 [92]. IEC 62660-2:2010 [87] and SAND2017-6925:2017 [107] also provide specific shape/design of the impactor for prismatic cells, whilst in GB/T 314852015:2015 [90] the impactor shape is completely different from all the standards and regulations. In regards to the dimensions of the impactor, it is different in all the selected standards and regulations.

Henceforth, the standards and regulations must have a clearly defined shape/design and the dimension of the impactor for testing cell, module, and pack for different types of batteries such as cylindrical and prismatic;

6. Number of testing samples: Multiple samples are needed for each test during the testing and in the majority of cases, the testing degrades the TD and therefore reusing the samples is not acceptable [115]. However, after considering the selected standards and regulation, it can be identified that standards such as SAE J2464:2009 [89] and FreedomCAR:2006 [92] overlap each other up to a certain extent but vary significantly in terms of the TD axes during the test. Comparing these two standards with GB/T 31485-2015:2015 [40] and SAND2017-6925:2017 [107], it is found that there is no clarity in terms of cell, module, or pack level testing samples. Considering the ISO 12405$3: 2014$ [84] standard there is a freedom to opt for the regional regulation but the 
axes should be defined by manufacturers which is certainly bewilderment for the manufacturers. In addition, UN/ECE-R100.02:2013 [98], IEC 62660-2:2010 [87] and, GTR 20:2018 [108] lack such information of sampling.

Henceforth, it can be said that despite the government and associated standards and regulations developing bodies being aware of the situation of confusion among the battery manufacturers along with the concept of increment in the cost linked with the number of test samples, there is no clear guidance for the manufacturers available.

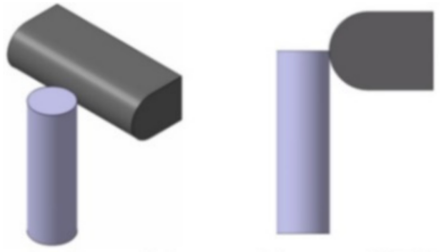

a) Crushing at top of TD

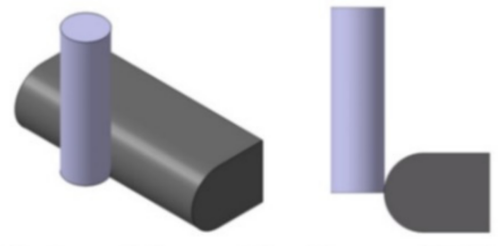

b) Crushing at bottom of TD

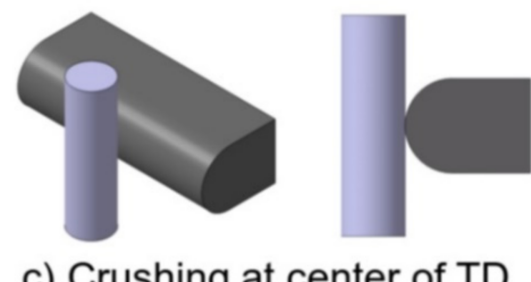

c) Crushing at center of TD

Figure 11. Point of contacts between impactor and TD from 3D view and front view, (a) top view; (b) bottom view; (c) centre view.

From the above points, it can be noticed that there is a need for the harmonisation of standards and regulations. Similar thoughts are also shared by Ruiz et al., Wech et al. and Justen and Schöneburg that a standard framework for battery testing can be used globally $[113,119,120]$. However, it is good that such a proposal was considered by the Global Technical Regulation on Electric Vehicle Safety [108] in the year 2018. Though, there is no significant development and impact that has been noticed since then at the market level. Therefore, it is important to take some further actions and implement them.

Moreover, along with the need for harmonising the current standards and regulations, there is also the need to augment them by considering real-life accident and crash scenarios. It was identified that in all these standards and the regulations, the battery is static and the crusher moves towards the TD, however, in real-life, the battery has a dynamic nature (as it is installed in the vehicle), which means that the battery is moving towards the impact zone. In real accidents, the loading of batteries occurs in two different ways:

- Impact forces from the contact of the vehicle with the collision partner: Here it is difficult to analyse the kind of collision and the impact severity. During the crash acceleration and specifically deceleration, values can be significantly high. For example, in a crash test carried out by the University of Zilinia, the deceleration of an accumulator mounted at the rear of the vehicle was approximately $500 \mathrm{~m} / \mathrm{s}^{2}$ in an impact with a rigid concrete barrier at a speed of $54 \mathrm{~km} / \mathrm{h}$ (refer Figure 12) [121]. In such a scenario, the batteries are dynamically loaded, and even if no mechanical damage is displayed on the surface of the battery, there is often internal damage that takes a relatively long time to show its effect;

- The intrusion of the other parts or deformation of the battery: In this case, the static test provides a good approximation of reality. The battery and vehicle construction play an vital role along with the placement of battery and fastening system [121]. 


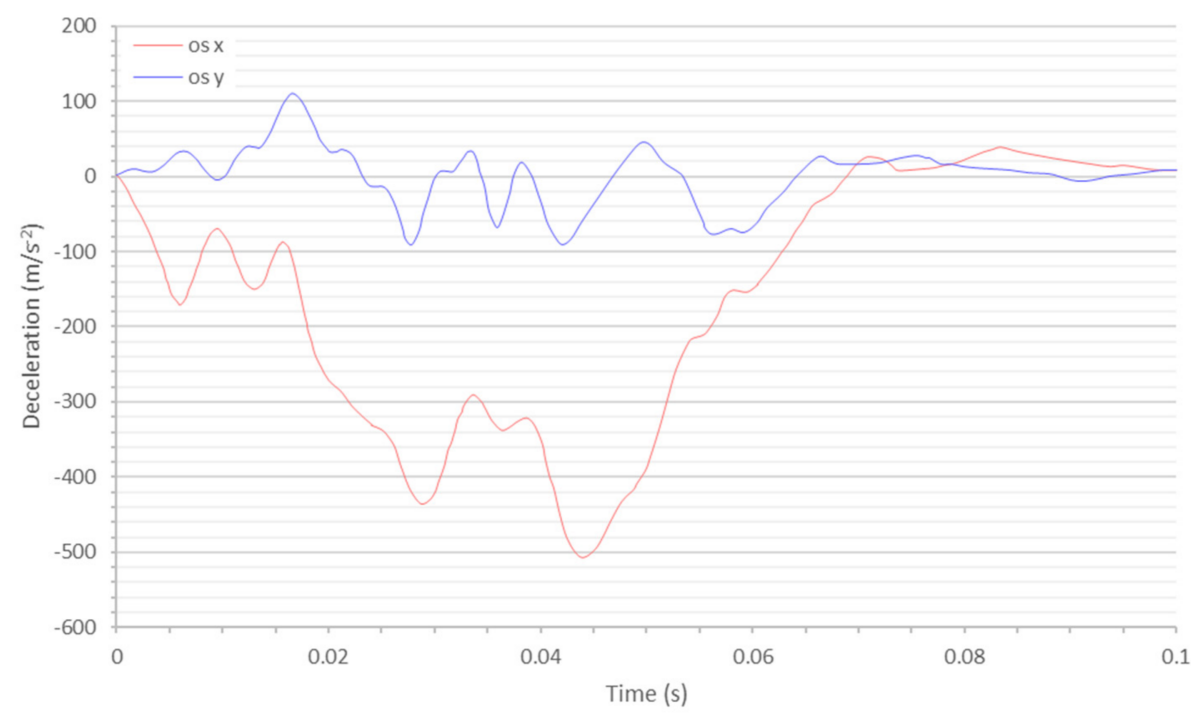

Figure 12. Decelerations during a crash test (speed: $54 \mathrm{~km} / \mathrm{h}$, rigid barrier, full overlap, $0^{\circ}$ impact angle) [121].

In the case of severe crashes or impacts, it is a combination of both. Usually, accidents often have complicated sequences. In such events, the crash data recorder (CDR) storage systems can serve as a good indicator. It would be useful to develop a methodology for battery diagnostics associated with the CDR system and constantly improve it with the help of testing. Researchers such as Wech et al., Justen and Schöneburg also agree with this and have also demonstrated some discrepancies between the results obtained through dynamic against static tests $[119,120]$.

Another concerning aspect is the comparability of results between the tests performed at the component level (on the cell, module, or pack) against the actual vehicles [58]. For example, in the latter case, the battery is protected by the battery enclosure and the chassis of the vehicle. Hence, the authenticity and reliability of the results obtained from a test conducted on a TD as per specific standards are in question.

\section{Conclusions}

Overall, after analysing multifarious standards and regulations, it can be concluded that energy storage in vehicles has always been associated with several risks. The combustion engine vehicles that are used in today's world took several decades to reach current safety standards and a similar challenge of time consumption and technological advancement is currently faced by EVs. However, the development time can be significantly shortened by modern technologies, as well as experience from previous and ongoing research.

After analysing the selected standards and regulations, it was identified that the ambiguities need to be removed and clarity can be provided in terms of testing procedures that are dedicated for cell, module, and pack level testing. For example, Table 9 shows such ambiguity for the selected standards and regulations against the crush parameters such as procedure, crushing speed, SoC, press position, crusher shape and dimensions, and the number of testing samples at the cell, module and pack level. Moreover, further ambiguity needs to be resolved, such as the acceptance criteria mentioned in UN/ECE-R100.02:2013, which should also be mentioned by other standards and regulations. 
Table 9. Ambiguity in standards and regulations for crush parameters different levels.

\begin{tabular}{cccc}
\hline \multirow{2}{*}{ Standards and Regulations } & \multicolumn{3}{c}{ Crush Parameters ${ }^{\mathbf{1}}$ Levels } \\
\cline { 2 - 4 } & Cell & Module & Pack \\
\hline SAE J2464:2009 & $\checkmark$ & $\checkmark$ & $\checkmark$ \\
ISO 12405-3:2014 & $\times$ & $\times$ & $\checkmark$ \\
IEC 62660-2:2010 & $\checkmark$ & $\checkmark$ & $\checkmark$ \\
FreedomCAR:2006 & $\checkmark$ & $\checkmark$ & $\checkmark$ \\
SAND2017-6925:2017 & $\checkmark$ & $\checkmark$ & $\checkmark$ \\
GB/T 31485-2015:2015 & $\checkmark$ & $\checkmark$ & $\checkmark$ \\
UN/ECE-R100.02:2013 & $\times$ & $\checkmark$ & $\checkmark$ \\
GTR 20:2018 & $\times$ & $\checkmark$ & \\
\hline
\end{tabular}

${ }^{1}$ Procedure, crushing speed, $\mathrm{SoC}$, press position, crusher shape and dimensions, and number of testing samples

Moreover, it is also concluded that (a) there is a scope of harmonisation of standards and regulations, and the current proposals should be investigated with priority and should be implemented in the market, and (b) augmentation can be performed by considering real-life vehicle crash scenarios, i.e., dynamic behaviour of the vehicle. Future works that can be performed are (a) the study of the impactor material, i.e., cell failure behaviour based on different impactor materials, and (b) comparison between the test outcomes, i.e., the impact of SoC on cell failure behaviour, carried out according to different standards and regulations. Altogether, it can be said if these steps are adopted then certainly battery and EV manufacturers will have significant ease during the manufacturing and approval processes and will also enhance the safety of EV consumers.

Author Contributions: Conceptualization, B.K., Y.K., H.-G.S. and K.B.; methodology, B.K., Y.K., H.G.S. and K.B.; formal analysis, B.K. and Y.K.; investigation, B.K. and Y.K.; resources, B.K., Y.K., H.-G.S., K.B. and T.K.; data curation, B.K., Y.K., H.-G.S., K.B. and T.K.; writing-original draft preparation, B.K. and Y.K.; writing-review and editing, B.K., Y.K., H.-G.S. and K.B.; supervision, H.-G.S.; funding acquisition, H.-G.S. All authors have read and agreed to the published version of the manuscript.

Funding: This research was funded by, (i) EFRE-supported EU research network project SENSE BAY, grant number EU-1802-0005, and (ii) HORIZON 2020-supported EU project COBRA, grant number H2020-EU.3.4.-875568.

Institutional Review Board Statement: Not applicable.

Informed Consent Statement: Not applicable.

Data Availability Statement: Not applicable.

Conflicts of Interest: The authors declare no conflict of interest.

\section{Abbreviations}

$\begin{array}{ll}\text { ANL } & \text { Argonne National Laboratory } \\ \text { BEVs } & \text { Battery Electric Vehicles } \\ \text { C } & \text { Cell } \\ \text { CDR } & \text { Crash Data Recorder } \\ \text { CEN } & \text { European Committee for Standardisation } \\ \text { CENELEC } & \text { European Committee for Electrotechnical Standardization } \\ \text { CNG } & \text { Compressed Natural Gas } \\ \text { DC } & \text { Direct-Current } \\ \text { DoE } & \text { The United States Department of Energy } \\ \text { ECHA } & \text { European Chemical Agency } \\ \text { ECOSOC } & \text { The United Nations Economic and Social Council } \\ \text { EESS } & \text { Electrical Energy Storage System } \\ \text { ESOs } & \text { European Standards Organizations }\end{array}$




\begin{tabular}{|c|c|}
\hline EU & Europe \\
\hline EV & Electric Vehicle \\
\hline EVs & Electric Vehicles \\
\hline EVS & Electric Vehicle Safety \\
\hline FMVSS & Federal Motor Vehicle Safety Standards \\
\hline $\mathrm{H}$ & Height \\
\hline $\mathrm{HE}$ & High Energy \\
\hline HEVs & Hybrid Electric Vehicles \\
\hline $\mathrm{HP}$ & High Power \\
\hline HSL & Hazard Safety Level \\
\hline ICE & Internal Combustion Engines \\
\hline IEA & International Energy Agency \\
\hline IEC & International Electrotechnical Commission \\
\hline ILTVA & International Light Transportation Vehicle Association \\
\hline INEEL & Idaho National Engineering and Environmental Laboratory \\
\hline INEL & Idaho National Engineering Laboratory \\
\hline ISO & International Organisation for Standardisation \\
\hline JRC & Joint Research Centre \\
\hline $\mathrm{L}$ & Length \\
\hline LFP & Lithium Iron Phosphate \\
\hline LNG & Liquefied Natural Gas \\
\hline M & Module \\
\hline NHTSA & National Highway Traffic Safety Administration \\
\hline $\mathrm{P}$ & Pack \\
\hline $\mathrm{R}$ & Radius \\
\hline $\mathrm{REACH}$ & $\begin{array}{l}\text { Regulation on the Registration, Evaluation, Authorisation and } \\
\text { Restriction of Chemicals }\end{array}$ \\
\hline REESS & Rechargeable Energy Storage System \\
\hline Reg & Regulation \\
\hline RESS & Rechargeable Energy Storage System \\
\hline SAC & Standardization Administration of China \\
\hline SAE & Society of Automotive Engineers International \\
\hline SNL & Sandia National Laboratory \\
\hline SoC & State of charge \\
\hline Std & Standard \\
\hline $\mathrm{T}$ & Thickness \\
\hline TC & Technical Committee \\
\hline TD & Test Device \\
\hline UNECE & United Nations Economic Commission for Europe \\
\hline UNECE & United Nations Economic Commission for Europe \\
\hline US & United States \\
\hline USA & United States of America \\
\hline USABC & United States Advanced Battery Consortium \\
\hline W & Width \\
\hline
\end{tabular}

\section{References}

1. $\mathrm{Wu}, \mathrm{S} . ;$ Xiong, R.; Li, H.; Nian, V.; Ma, S. The state of the art on preheating lithium-ion batteries in cold weather. J. Energy Storage 2020, 27, 101059. [CrossRef]

2. Zhang, Q.; Dong, Q.-F.; Zheng, M.-S.; Tian, Z.-W. Electrochemical Energy Storage Device for Electric Vehicles. J. Electrochem. Soc. 2011, 158, A443. [CrossRef]

3. Kotak, B.; Kotak, Y. Review of E European Regu ulations and Germany's Action to Reduce Automotive Sector Emissions. Trasp. Eur. 2016, 7, 1-19.

4. Wegmann, R.; Döge, V.; Becker, J.; Sauer, D.U. Optimized operation of hybrid battery systems for electric vehicles using deterministic and stochastic dynamic programming. J. Energy Storage 2017, 14, 22-38. [CrossRef]

5. Bandhauer, T.M.; Garimella, S.; Fuller, T.F. A Critical Review of Thermal Issues in Lithium-Ion Batteries. J. Electrochem. Soc. 2011, 158, R1. [CrossRef]

6. Spray, R.; Barry, M.; Vickery, J. Understanding Downstream Risk from Lithium-Ion Battery Thermal Runaway \& Designing for Safety. ECS Trans. 2019, 89, 65-71. [CrossRef] 
7. Visintin, A.; Thomas, J.E.; Becker, M.D.; Castro, B.; Milocco, R.; Real, S.; Sacco, J.; Garaventta, G.N.; Triaca, W.E. (Keynote Lecture) The Research on Lithium-Ion Batteries for Electric Cars in the Universidad Nacional de La Plata. ECS Trans. 2019, 40, 67-73. [CrossRef]

8. Messier, P.; Nguyễn, B.-H.; LeBel, F.-A.; Trovão, J.P.F. Disturbance observer-based state-of-charge estimation for Li-ion battery used in light electric vehicles. J. Energy Storage 2020, 27, 101144. [CrossRef]

9. Alessandrini, S.; Rizzuto, E.; Del Prete, Z. Characterizing different types of lithium ion cells with an automated measurement system. J. Energy Storage 2016, 7, 244-251. [CrossRef]

10. Wang, W.; Yang, S.; Lin, C. Clay-like mechanical properties for the jellyroll of cylindrical Lithium-ion cells. Appl. Energy 2017, 196, 249-258. [CrossRef]

11. Hawkins, T.R.; Singh, B.; Majeau-Bettez, G.; Strømman, A.H. Comparative Environmental Life Cycle Assessment of Conventional and Electric Vehicles. J. Ind. Ecol. 2013, 17, 53-64. [CrossRef]

12. Malifarge, S.; Delobel, B.; Delacourt, C. Experimental and Modeling Analysis of Graphite Electrodes with Various Thicknesses and Porosities for High-Energy-Density Li-Ion Batteries. J. Electrochem. Soc. 2018, 165, A1275-A1287. [CrossRef]

13. Mohanty, P.; Kotak, Y. Electric vehicles: Status and roadmap for India. In Electric Vehicles: Prospects and Challenges; Muneer, T., Kolhe, M.L., Doyle, A., Eds.; Elsevier Inc.: Amsterdam, The Netherlands, 2017; pp. 387-414.

14. Machuca, E.; Steger, F.; Vogt, J.; Brade, K.; Schweiger, H.G. Availability of Lithium Ion Batteries from Hybrid and Electric Cars for Second Use: How to Forecast for Germany until 2030. J. Electr. Eng. 2018, 6, 129-143. [CrossRef]

15. Schweiger, H.-G. Zukunft in Bewegung-Automobile Antriebskonzepte in der Diskussion 2019. Available online: https: //www.researchgate.net/publication/333868327_Elektromobilitat_Aktueller_Stand_und_Ausblick (accessed on 10 June 2021).

16. Vaughan, A.; Electric Cars Exceed $1 \mathrm{~m}$ in Europe as Sales Soar by More Than 40\%. The Guard. Available online: https:/ / www.theguardian.com/environment/2018/aug/26/electric-cars-exceed-1m-in-europe-as-sales-soar-by-morethan-40-per-cent\#top (accessed on 10 April 2021).

17. Shell Deutschland Oil GmbH. Shell Passenger Car SCenarios for Germany to 2040; Shell Deutschland Oil GmbH: Hamburg, Germany, 2014.

18. Kugler, U.; Schimeczek, C.; Klötzke, M.; Schmid, S.; Gis, W.; Järvi, T.; Auvinen, H. Scenario Report, with an in-Depth Description of the Scenarios' Background (D 6.2); eMap-German Aerospace Center (DLR), Motor Transport Institute (ITS) \& Technical Research Centre of Finland Ltd. (VTT): Stuttgart, Germany, 2015.

19. IEA. Global EV Outlook 2020; IEA: Paris, Frence, 2020.

20. Power Technology. The Most Promising Renewable Trends for Electric Vehicles. Available online: https://www.powertechnology.com/comment/promising-renewable-trends-electric-vehicles/ (accessed on 2 April 2021).

21. Khan, B. The World Is on the Brink of an Electric Car Revolution. Available online: https://www.climatecentral.org/news/ world-electric-car-revolution-21597 (accessed on 5 April 2021).

22. Spielbauer, M.; Berg, P.; Ringat, M.; Bohlen, O.; Jossen, A. Experimental study of the impedance behavior of 18650 lithium-ion battery cells under deforming mechanical abuse. J. Energy Storage 2019, 26, 101039. [CrossRef]

23. Wang, W.; Yang, S.; Lin, C.; Li, Y. Mechanical and electrical response of cylindrical Lithium-ion cells at various State of Charge. Energy Procedia 2018, 145, 128-132. [CrossRef]

24. Goodman, J.K.S.; Miller, J.T.; Kreuzer, S.; Forman, J.; Wi, S.; Choi, J.; Oh, B.; White, K. Lithium-ion cell response to mechanical abuse: Three-point bend. J. Energy Storage 2020, 28, 101244. [CrossRef]

25. Pan, Z.; Li, W.; Xia, Y. Experiments and 3D detailed modeling for a pouch battery cell under impact loading. J. Energy Storage 2020, 27, 101016. [CrossRef]

26. Bisschop, R.; Willstrand, O.; Amon, F.; Rosengren, M. Fire Safety of Lithium-Ion Batteries in Road Vehicles; RISE Research Institutes of Sweden: Gothenburg, Sweden, 2019.

27. Zhao, W.; Luo, G.; Wang, C.-Y. Modeling Internal Shorting Process in Large-Format Li-Ion Cells. J. Electrochem. Soc. 2015, 162, A1352-A1364. [CrossRef]

28. Larsson, F. Lithium-ion Battery Safety-Assessment by Abuse Testing, Fluoride Gas Emissions and Fire Propagation. Ph.D. Thesis, Chalmers University of Technology, Gothenburg, Sweden, 2017.

29. Santhanagopalan, S.; Ramadass, P.; Zhang, J. Analysis of internal short-circuit in a lithium ion cell. J. Power Sources 2009, 194, 550-557. [CrossRef]

30. Zhu, J.; Wierzbicki, T.; Li, W. A review of safety-focused mechanical modeling of commercial lithium-ion batteries. J. Power Sources 2018, 378, 153-168. [CrossRef]

31. Trattnig, G.; Leitgeb, W. Battery Modelling for Crash Safety Simulation. In Automotive Battery Technology; Springer International Publishing: Berlin/Heidelberg, Germany, 2014; pp. 19-35.

32. Hendricks, C.; Williard, N.; Mathew, S.; Pecht, M. A failure modes, mechanisms, and effects analysis (FMMEA) of lithium-ion batteries. J. Power Sources 2015, 297, 113-120. [CrossRef]

33. Li, W.; Xia, Y.; Chen, G.; Sahraei, E. Comparative study of mechanical-electrical-thermal responses of pouch, cylindrical, and prismatic lithium-ion cells under mechanical abuse. Sci. China Technol. Sci. 2018, 61, 1472-1482. [CrossRef]

34. Jeevarajan, J.A.; Hall, A. Study of the Intrinsic Safety Features in a Cylindrical Li-Ion Cell. ECS Trans. 2019, 1, 1-5. [CrossRef]

35. Liao, Z.; Zhang, S.; Li, K.; Zhao, M.; Qiu, Z.; Han, D.; Zhang, G.; Habetler, T.G. Hazard analysis of thermally abused lithium-ion batteries at different state of charges. J. Energy Storage 2020, 27, 101065. [CrossRef] 
36. Mier, F.A.; Morales, R.; Coultas-McKenney, C.A.; Hargather, M.J.; Ostanek, J. Overcharge and thermal destructive testing of lithium metal oxide and lithium metal phosphate batteries incorporating optical diagnostics. J. Energy Storage 2017, 13, 378-386. [CrossRef]

37. Gehandler, J.; Karlsson, P.; Vylund, L. Risks Associated with Alternative Fuels in Road Tunnels and Underground Garages; SP Technical Research Institute of Sweden: Borås, Sweden, 2017.

38. Danish Maritime Accident Investigation Board. Pearl of Scandinavia Fire-Marine Accident Report; Danish Maritime Accident Investigation Board: Copenhagen, Denmark, 2010.

39. Auto Web Hangzhou Halts All Electric Taxis as a Zotye Langyue (Multipla) EV Catches Fire. Available online: http:// chinaautoweb.com/2011/04/hangzhouhalts-all-electric-taxis-as-a-zotye-langyue-multipla-ev-catches-fire/ (accessed on 15 December 2020).

40. Smith, B. Chevrolet Volt Battery Incident Summary Report; US Department of Transportation, National Highway Traffic Safety Administration: Washington, DC, USA, 2012.

41. Sturk, D.; Hoffmann, L. E-Fordons Potentiella Riskfaktorer vid Trafikskadehändelse; SP Technical Research Institute of Sweden: Borås, Sweden, 2013.

42. Voelcker, J. Second Fisker Karma Fire Casts Fresh Doubt on Plug-In Hybrid. Available online: https: / / www.greencarreports. com/news/1078412_second-fisker-karma-fire-casts-fresh-doubt-on-plug-in-hybrid (accessed on 13 January 2021).

43. Garthwaite, J. Mystery at Port Newark: Why Did 17 Plug-In Cars Burn? Available online: https:/ / wheels.blogs.nytimes.com/20 12/11/02/mystery-at-port-newark-why-did-17-plug-in-cars-burn/ (accessed on 12 February 2021).

44. McPartland, B. Paris Autolib' Electric Cars Go up in Smoke. Available online: https:/ / www.thelocal.fr/20131014/in-imagestwo-autolib-cars-go-up-in-smoke-in-paris/ (accessed on 10 April 2021).

45. Godfrey, W. Investigation: PE 13-037-Fire-Propulsion Battery-Road Debris. 2014. Available online: https://www.autosafety.org/ wp-content/uploads/import/TeslaBatteryClosingMemo.pdf (accessed on 13 March 2021).

46. Loveday, E. Mitsubishi Extends Production Halt on Outlander PHEV as Perplexing Battery Investigation Continues. Available online: https:/ / insideevs.com/news/317625/mitsubishi-extends-production-halt-on-outlander-phev-as-perplexing-batteryinvestigation-continues/ (accessed on 15 March 2021).

47. Lopez, L. Another Tesla Caught On Fire While Sitting in a Toronto Garage This Month. Available online: https://www. businessinsider.in/another-tesla-caught-on-fire-while-sitting-in-a-toronto-garage-this-month/articleshow /30366384.cms (accessed on 20 March 2021).

48. Bolstad, K.; Urstad, T. Personbil Påkjørt Av Toget i Råde. Available online: https://www.moss-avis.no/nyheter/rade/ togulykker/personbil-pakjort-av-toget-i-rade/s/5-67-193113 (accessed on 29 March 2021).

49. Brandt, P. Brandorsaken Hos Tesla Model S i Norge Klarlagd-Kortslutning. Available online: https://www.mestmotor. se/automotorsport/artiklar/nyheter/20160319/brandorsaken-hos-tesla-model-s-i-norge-klarlagd-kortslutning/ (accessed on 10 March 2021).

50. Lambert, F. Tesla Says Model S Fire in France Was Due to 'Electrical Connection Improperly Tightened' by a Human Instead of Robots. Available online: https:/ / electrek.co/2016/09/09/tesla-fire-france-electrical-connection-improperly-tightened-humanrobot/ (accessed on 3 April 2021).

51. Evans, A. Electric Car Bursts into Flames and Burns to the Ground after it was Left Charging Overnight 'at a Faulty Power Point. Available online: https:/ / www.dailymail.co.uk/news/article-4679416/Electric-car-left-chargingovernight-destroyed-fire.html (accessed on 1 March 2021).

52. Lambert, F. (a) Tesla Owner Asks for $\$ 1$ Million after Model X Caught on Fire in Crash and Falcon Wing Doors Wouldn't Open. Available online: https://electrek.co/2017/04/23/tesla-model-x-fire-crash-falcon-wing-doors-stuck/ (accessed on 17 June 2021).

53. Barth, T.; Robert, S. NTSB Investigations of EV Fires Electric Vehicle Safety IWG Global Technical Regulation Session 16. Available online: https:/ / wiki.unece.org/download/attachments/60358932/EVS16-E7OI-0600\%5BUS\%5DNTSBelectricvehiclefireinvestigations. pdf?api=v2 (accessed on 25 June 2021).

54. Online Reporters Porsche Catches Fire while Charging. Available online: https://www.bangkokpost.com/news/general/142951 8/ porsche-catches-firewhile-charging (accessed on 2 April 2021).

55. Brandt, P. Jaguar I-Pace Fattade Eld i Nederländerna-Beskrivs Som “Termisk Incident". Available online: https: //www.mestmotor.se/recharge/artiklar/nyheter/20181211/jaguar-i-pace-fattade-eld-i-nederlanderna-beskrivs-som-ermiskincidentav-jaguar/ (accessed on 12 March 2021).

56. Pearson-JonesBridie New Tesla Car Bursts into Flames TWICE in a Day with Firefighters Using 2000 Gallons of Water to Battle Blaze. Available online: https:/ / www.dailymail.co.uk/news/article-6519645/Tesla-car-catches-fire-3times-one-day-firefightersbattle-blaze-2000-gallons-water.html (accessed on 26 April 2021).

57. Technology Tesla Car Catches Fire in China, Investigation Underway. Available online: https://news.cgtn.com/news/3d3d514 d7a416a4d34457a6333566d54/index.html (accessed on 17 March 2021).

58. Loveday, S. BMW i3 REx Burns after Catching Fire while Parked in Spain. Available online: https://insideevs.com/news/337258 /bmw-i3-rex-burns-after-catching-fire-while-parked-in-spain/ (accessed on 9 May 2021).

59. NTSB. Preliminary Report: Crash and Post-Crash Fire of Electric-Powered Passenger Vehicle; NTSB: Washington, DC, USA, 2018.

60. Zhou, X. Frequent Fire Accidents on Electric Vehicle. Operators 2018, 10, 65-66. 
61. NTSB. (a) Preliminary Report: Highway HWY18FH013; National Transportation Safety Board: Washington, DC, USA, 2018.

62. Revill, J. Tesla Crash may have Triggered Battery Fire: Swiss Firefighters. Available online: https://www.reuters.com/article/usswiss-tesla-crash-idUSKCN1IF2WN (accessed on 7 March 2021).

63. NTSB. (b) Preliminary Report-Battery Fire in Electric-Powered Passenger Car; National Transportation Safety Board: Washington, DC, USA, 2018.

64. Deick, M. Van Gloednieuwe Auto Verwoest Door Brand in Rumpt. Available online: https://www.zakengidstiel.nl/nieuws/ algemeen/587262/gloednieuwe-auto-verwoest-door-brand-in-rumpt (accessed on 4 April 2021).

65. Gutman, M.; Youn, S. Firefighters Work 16 Hours to Put Out Fires in Tesla Model S. Available online: https://abcnews.go.com/ Technology/tesla-opens-investigation-car-burst-flames-times/story?id=59930420 (accessed on 17 March 2021).

66. Jolicoeur, C. BMW i8 Catches Fire in Europe Dealership, Gets Dropped in Huge Bath. Available online: https://motorillustrated. com/bmw-i8-catches-fire-in-europe-dealership-gets-dropped-in-huge-bath/23440/ (accessed on 10 April 2021).

67. Huang, E. Electric Vans from One of China's Biggest EV Makers Are Catching Fire. Available online: https://qz.com/1575817/ electric-vehicles-from-chinese-car-maker-bjev-are-catching-fire/ (accessed on 3 April 2021).

68. Ke, S. Tesla Investigating Explosion of Car in Shanghai. Available online: https://www.shine.cn/news/metro/1904223436/ (accessed on 22 March 2021).

69. Kermani, G.; Sahraei, E. Review: Characterization and Modeling of the Mechanical Properties of Lithium-Ion Batteries. Energies 2017, 10, 1730. [CrossRef]

70. Zhang, M.; Liu, L.; Stefanopoulou, A.; Siegel, J.; Lu, L.; He, X.; Ouyang, M. Fusing Phenomenon of Lithium-Ion Battery Internal Short Circuit. J. Electrochem. Soc. 2017, 164, A2738-A2745. [CrossRef]

71. Hunt, I.A.; Patel, Y.; Szczygielski, M.; Kabacik, L.; Offer, G.J. Lithium sulfur battery nail penetration test under load. J. Energy Storage 2015, 2, 25-29. [CrossRef]

72. Kim, W.-K.; Steger, F.; Kotak, B.; Knudsen, P.; Girgsdies, U.; Schweiger, H.-G. Water Condensation in Traction Battery Systems. Energies 2019, 12, 1171. [CrossRef]

73. Kotak, B. (a) Need for Safer Standards and Regulation of Lithium-Ion Battery. In Proceedings of the 10th Annual Battery Saftey Summit, Alexandria, VA, USA, 22-25 October 2019; Cambridge EnerTech: Needham, MA, USA, 2019.

74. Union of Concerned Scientist Electric Vehicle Batteries: Materials, Cost, Lifespan. Available online: https: / / www.ucsusa.org/ resources/ev-batteries\#toc-materials (accessed on 19 March 2021).

75. Zhao, W.; Luo, G.; Wang, C.-Y. Modeling Nail Penetration Process in Large-Format Li-Ion Cells. J. Electrochem. Soc. 2015, 162, A207-A217. [CrossRef]

76. Lunz, B.; Sauer, D.U. Electric road vehicle battery charging systems and infrastructure. In Advances in Battery Technologies for Electric Vehicles; Elsevier: Amsterdam, The Netherlands, 2015; pp. 445-467.

77. CEN. What Is a Standard? Available online: https://www.cen.eu/work/endev/whatisen/pages/default.aspx (accessed on 12 April 2021).

78. CEN. (a) Compass; CEN-The World of European Standards; CEN: Brussels, Belgium, 2010.

79. CEN. (b) Technical Bodies. Available online: https://standards.cen.eu/dyn/www/f?p=CENWEB:6:::NO::: (accessed on 19 March 2021).

80. CEN. (c) CEN Deliverables. Available online: https://boss.cen.eu/reference-material/guidancedoc/pages/del (accessed on 10 April 2021).

81. CEN-CENLEC About Us. Available online: https://www.cencenelec.eu/aboutus/Pages/default.aspx (accessed on 2 February 2021).

82. CENLEC. CENELEC Facts and Figures. Available online: https://www.cenelec.eu/aboutcenelec/whatwedo/factsandfigures/ index.html (accessed on 30 March 2021).

83. Dossett, D. The European Standardization System in support of e-mobility. In Proceedings of the International Symposium 'Towards a Transatlantic E-Mobility Market', CEN-CENLEC, Ispra, Italy, 28-29 October 2015; pp. 1-21.

84. ISO Electrically Propelled Road Vehicles-Test Specification for Lithium-Ion Traction Battery Packs and Systems—Part 3: Safety Performance Requirements-ISO 12405-3:2014. Available online: https://www.iso.org/standard/59224.html (accessed on 13 April 2021).

85. CEN-CENLEC. (a) ISO \& IEC. Available online: https://www.cencenelec.eu/intcoop/StandardizationOrg/Pages/default.aspx (accessed on 3 March 2021).

86. ISO. (a) About US. Available online: https://www.iso.org/about-us.html (accessed on 17 May 2021).

87. IEC. Secondary Lithium-Ion Cells for the Propulsion of Electric Road Vehicles_Part 2: Reliability and Abuse Testing; International Electrotechnical Commision: Geneva, Switzerland, 2018.

88. IEC. (a) What We Do. Available online: https://www.iec.ch/what-we-do (accessed on 5 February 2021).

89. SAE. Electric and Hybrid Electric Vehicle Rechargeable Energy Storage System (RESS) Safety and Abuse Testing-SAE J2464:2009; SAE International: Washington, DC, USA, 2009.

90. GB - Chinese National Standard. Safety Requirements and Test Methods for Traction Battery of Electric Vehicle—GB/T 31485-2015; Chinese National Standard: Beijing, China, 2015. 
91. Ruiz, V. Standards for the Performance and Durability Assessment of Electric Vehicle Batteries 2018. Available online: https: / / ec.europa.eu/jrc/en/publication/standards-performance-and-durability-assessment-electric-vehicle-batteries (accessed on 19 June 2021).

92. Doughty, D.H.; Crafts, C.C. FreedomCAR: Elaectrical Energy Storage System Abuse Test Manual for Electric and Hybrid Electric Vehicle Applications_FreedomCAR:2006; Sandia National Laboratories; SNL: Albuquerque, NM, USA; Livermore, CA, USA, 2006.

93. Focus Laws vs. Regulations vs. Standards. Available online: https://www.focusstandards.org/standards-vs-regulations-vslaws/ (accessed on 9 April 2021).

94. AEM Regulations VS Standards: Clearing Up the Confusion. Available online: https://www.aem.org/news/regulations-vsstandards-clearing-up-the-confusion (accessed on 10 April 2021).

95. European Union European Chemicals Agency (ECHA). Available online: https://europa.eu/european-union/about-eu/ agencies/echa_en (accessed on 18 March 2021).

96. ECHA Understanding REACH. Available online: https:/ / echa.europa.eu/en/regulations/reach/understanding-reach (accessed on 17 February 2021).

97. ECHA. (a) Batteries Directive. Available online: https://echa.europa.eu/legislation-profile/-/legislationprofile/EU-BATTERIES (accessed on 9 April 2021).

98. European Union (b). Uniform Provisions Concerning the Approval of Vehicles with Regard to Specific Requirements for the Electric Power train-UN/ECE-R100; Publication Office of the European Union: Luxembourg, 2015.

99. The National Highway Traffic Safety Administration about NHTSA. Available online: https://www.nhtsa.gov/about-nhtsa (accessed on 5 February 2021).

100. U.S. Department of Transportation. Motor Vehicle Safety; National Highway Traffic Safety Administration (NHTSA): Washington, DC, USA, 2008.

101. Green, J.; Hartman, B.; Glowacki, P. A System-based View of the Standards and Certification Landscape for Electric Vehicles. World Electr. Veh. J. 2016, 8, 564-575. [CrossRef]

102. Gao, S.; Feng, X.; Lu, L.; Ouyang, M.; Ren, D. A Test Approach for Evaluating the Safety Considering Thermal Runaway Propagation within the Battery Pack. ECS Trans. 2017, 77, 225-236. [CrossRef]

103. Mulder, G.; Trad, K.; Ried, S.; Sotta, D. Advanced Materials for Batteries; MAT4BAT. Available online: https://www. batterystandards.info/sites/batterystandards.info/files/mat4bat_d5.6_m42_recommendations_further_development_ regulations_and_standards.pdf (accessed on 20 June 2021).

104. Underwriters Laboratories. Safety Issues for Lithium-Ion Batteries; Northbrook: Chicago, IL, USA, 2011.

105. Leuthner, S. Lithium-Ion Batteries: Basics and Applications; Korthauer, R., Ed.; Springer: Berlin/Heidelberg, Germany, 2018.

106. Garche, J.; Brandt, K. (Eds.) Electrochemical Power Sources: Fundamentals, Systems, and Applications; Elsevier: Amsterdam, The Netherlands, 2019.

107. Orendorff, C.; Lamb, J.; Steele, L.A.M. Recommended Practices for Abuse Testing Rechargeable Energy Storage Systems (RESSs)— SAND2017-6925: 2017; Sandia National Laboratories: Albuquerque, NM, USA; Livermore, CA, USA, 2017.

108. United Nations. Global Technical Regulation on Electric Vehicle Safety (EVS)—GTR 20:2018; UNECE: Geneva, Switzerland, 2018.

109. Schweiger, H.-G. Energiemanagement und Energiespeichersysteme Presentation; Technische Hochschule Ingolstadt: Ingolstadt, Germany, 2020.

110. Lamb, J.; Torres-Castro, L.; Karulkar, M.; Stanley, J.; Grosso, C. Abuse Testing to Understand High Energy Battery Failure; Sandia National Lab.: Albuquerque, NM, USA, 2018.

111. Hu, L.L.; Zhang, Z.W.; Zhou, M.Z.; Zhang, H.J. Crushing behaviors and failure of packed batteries. Int. J. Impact Eng. 2020, 143, 103618. [CrossRef]

112. Mikolajczak, C.; Kahn, M.; White, K.; Long, R.T. Lithium-Ion Batteries Hazard and Use Assessment; Springer: Quincy, MA, USA, 2011.

113. Ruiz, V.; Pfrang, A.; Kriston, A.; Omar, N.; Van den Bossche, P.; Boon-Brett, L. A review of international abuse testing standards and regulations for lithium ion batteries in electric and hybrid electric vehicles. Renew. Sustain. Energy Rev. 2018, 81, 1427-1452. [CrossRef]

114. Sahraei, E.; Meier, J.; Wierzbicki, T. Characterizing and modeling mechanical properties and onset of short circuit for three types of lithium-ion pouch cells. J. Power Sources 2014, 247, 503-516. [CrossRef]

115. Millsaps, C. All Battery Tests Are Not Created Equal (Even When They Have the Same Name!). Available online: https: / /incompliancemag.com/article/all-battery-tests-are-not-created-equal-even-when-they-have-the-same-name/ (accessed on 7 February 2021).

116. Kisters, T.; Sahraei, E.; Wierzbicki, T. Dynamic impact tests on lithium-ion cells. Int. J. Impact Eng. 2017, 108, 205-216. [CrossRef]

117. Sheikh, M. State of Charge Dependent Thermal Runaway Detection of Lithium-Ion Battery under Mechanical Abuse Conditions. Ph.D. Thesis, University of Sunderland, Sunderland, UK, 2018.

118. Maleki, H.; Howard, J.N. Internal short circuit in Li-ion cells. J. Power Sources 2009, 191, 568-574. [CrossRef]

119. Wech, L.; Richter, R.; Justen, R.; Schoneburg, R. Crash Safety Aspects of HV Batteries for Vehicles. In Proceedings of the 22nd Enhanced Safety of Vehicles Conference (ESV 2011), Washington, DC, USA, 13-16 June 2011; National Highway Traffic Safety Administration (NHTSA): Washington, DC, USA, 2011; pp. 336-343. 
120. Justen, R.; Schoneburg, R. Crash Safety of Hybrid- and Battery Electric Vehicles. In Proceedings of the 22nd Enhanced Safety of Vehicles Conference (ESV 2011)Vehicles Conference (ESV 2011), Washington, DC, USA, 13-16 June 2011; National Highway Traffic Safety Administration (NHTSA): Washington, DC, USA, 2011; pp. 309-317.

121. University of Žilina. To Determine the Safety of the PV Fixing in the Interior and Boot of the Kia Ceed I.; University of Žilina: Žilina, Slovakia, 2014. 